PONTIFÍCIA UNIVERSIDADE CATÓLICA DO RIO DE JANEIRO

\title{
Apaixonados por Fusca: Um estudo sobre o consumo de um carro histórico.
}

\section{Pedro Consoni Alves}

Trabalho de Conclusão de Curso

Centro de CIÊnCIAS Socials - CCS DEPARTAMENTO DE AdMINISTRAÇÃO

Graduação em Administração de Empresas 


\section{Pedro Consoni Alves}

\section{Apaixonados por Fusca: Um estudo sobre o consumo de um carro histórico.}

Trabalho de Conclusão de Curso, apresentado ao programa de graduação em Administração da PUC-Rio como requisito parcial para a obtenção do titulo de graduação em Administração.

Orientadora: Marina Frid 


\section{Agradecimentos}

Agradeço a toda a minha família por me dar todo o suporte necessário para estar aqui hoje e especialmente meu pai e minha mãe, por cuidarem da nossa grande família da melhor forma possível. 


\title{
Resumo
}

Alves, Pedro. Apaixonados por Fusca: Um estudo sobre o consumo de um carro histórico. Rio de Janeiro, 2015. 34p. Trabalho de Conclusão de Curso

- Departamento de Administração. Pontifícia Universidade Católica do Rio de Janeiro.

O principal objetivo deste trabalho é identificar e descrever os motivos que levam o consumidor a comprar, manter e cuidar de um Fusca e como eles se sentem em relação ao automóvel. O estudo busca, além de entender estas motivações, descobrir quais lembranças, histórias e momentos marcantes os proprietários passaram com seus Fuscas para compreender a fundo o sentimento entre eles. Foram realizadas onze entrevistas com proprietários de Fuscas, moradores da cidade do Rio de Janeiro, com idades entre 22 a 75 anos, todas em ambientes informais.

\author{
Palavras-chave \\ Consumo, Fusca, nostalgia, estilo de vida.
}

\begin{abstract}
Alves, Pedro. Beetle Lover's: A study about the consumption of a historic car. Rio de Janeiro, 2015. 34p. Trabalho de Conclusão de Curso Departamento de Administração. Pontifícia Universidade Católica do Rio de Janeiro.
\end{abstract}

The main objective of this study is to identify and describe the reasons that lead a consumer to buy, maintain and take care of a beetle and how they feel their cars. The study aims, not only to understand these motivations, but to find out, memories, stories and memorable moments the owners spent with their beetles to deeply comprehend the feeling between them. Eleven interviews were made with differents beetle owners. Their ages were between 22 to 75 , and they all live in Rio de Janeiro. All the interviews were realized in informal places.

\section{Key-words}

Consumption, Beetle, nostalgia, life style. 


\section{Sumário}

1. O tema e o problema de estudo 1

1.1. Introdução ao tema e ao problema do estudo 1

1.2. Objetivos do estudo 6

1.3. Delimitação e foco do estudo

$\begin{array}{ll}\text { 1.4. Justificativa e relevância do estudo } & 7\end{array}$

2 Revisão de literatura 9

2.1. Comportamento do Consumidor e Cultura. 9

2.2. Estilos de Vida 11

$\begin{array}{ll}\text { 2.3. Marketing de Nostalgia } & 14\end{array}$

3 Métodos e procedimentos de coleta e de análise de dados do estudo 19

3.1. Estratégia de investigação ou Método de pesquisa utilizado 19

3.2. Procedimentos e instrumentos de coleta de dados utilizados no estudo 20

3.3. Formas de tratamento e análise dos dados coletados para o estudo 21

4 Apresentação e análise dos resultados 23

4.1. Resultado das entrevistas/Descrição e análise dos resultados 23

$\begin{array}{ll}5 \text { Conclusões } & 39\end{array}$

6 Referências Bibliográficas $\quad 40$

$\begin{array}{ll}\text { Anexo } 1 & 42\end{array}$ 


\section{Lista de figuras}

Figura 1: Primeiro carro movido a gasolina desenvolvido por Karl Benz ............. 2

Figura 2: Ford Modelo T Preto .................................................................. 2

Figura 3: Hitler no lançamento do Fusca 1938 ................................................ 3

Figura 4: Primeiro anuncio do Fusca no Brasil 1951 .......................................... 4

Figura 5: Itamar Franco no dia do relançamento. ........................................ 5

Figura 6: Anuncio da última produção de Fuscas no México ............................... 6

Figura 7: Fusca 1966 reformado com 4 portas. .......................................... 12

Figura 8: Fusca 1959 restaurado e conversível ......................................... 13

Figura 9: Fusca 1975 restaurado internamente.......................................... 13

Figura 10: Anuncio do Novo Fusca sobre o antigo ...................................... 15

Figura 11: Outra do Fusca em comemoração ao dia dos pais......................... 16

Figura 12: Versões do Fiat 500 (Novo x Antigo) .......................................... 16

Figura 13: Brastemp lançando linhas de eletrodomésticos retro...................... 17

Figura 14: Chocolate Lolo ................................................................ 17

Figura 15: Biscoito Mirabel ................................................................. 18

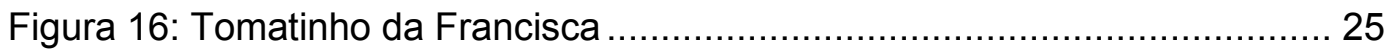

Figura 17: Fusca Pirulito ano 1968 .................................................... 27

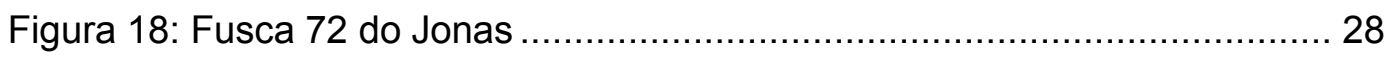

Figura 19: Fusca 1973 do Frederico........................................................ 30

Figura 20: Fábio e o Fubika ano 1974 .................................................... 31

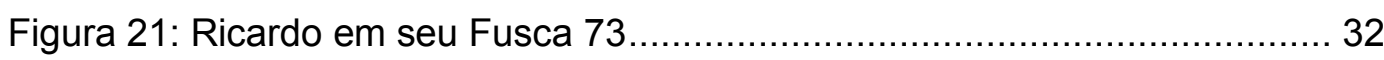

Figura 22: Fusca do Gabriel ano 70 .................................................... 33

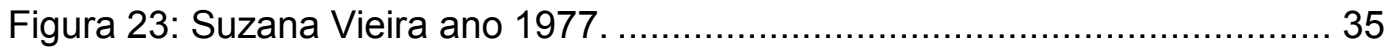

Figura 24: Otavio e sua mulher no Fusca ano 1969. .................................... 36

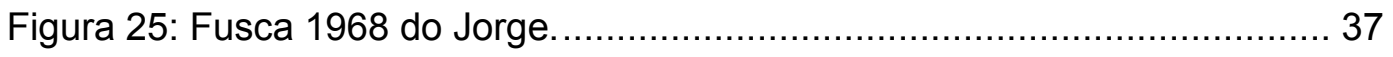

\section{Lista de Tabelas}

Tabela 1: Descrição dos entrevistados. 


\section{O tema e o problema de estudo}

\subsection{Introdução ao tema e ao problema do estudo}

Esse estudo pretende investigar aspectos do consumo do Fusca, um carro popular da Volkswagen lançado pela primeira vez há mais de 60 anos. Especificamente o trabalho busca analisar a relação do proprietário de Fusca com seus automóveis com a intenção de entender quais ideias, valores, imagens e sentimentos são vinculados a este modelo de carro. $O$ estudo em questão trata-se do modelo antigo do Fusca, não se refere ao New Beetle lançado em 2008 e nem ao Novo Fusca, lançado em 2013. O estudo foca em donos de Fuscas do Rio de Janeiro, Brasil, como forma de explorar possíveis motivações para a aquisição e manutenção desse tipo de automóvel, que já não é mais fabricado.

O mercado automobilístico evolui constantemente, e os grandes players do mercado investem grande quantidade de dinheiro em tecnologia, e em P\&D para desenvolver carros com aerodinâmica mais moderna e motores mais potentes.

Empresas do setor automobilístico investem intensivamente em Pesquisa \& Desenvolvimento para poder desfrutar de tecnologias e produtos avançados (CARVALHO, 2007).

Mais recentemente, principalmente a partir de meados dos anos 1990, observa-se também um crescente empenho das grandes empresas automobilísticas como, por exemplo, GM e Ford, bem como, empresas aéreas como Boeing, no desenvolvimento das chamadas tecnologias automotivas avançadas (CARVALHO, 2007).

Porém, não foi sempre assim. O primeiro carro movido à gasolina foi desenvolvido por Karl Benz, em meados de 1886 na Alemanha. O carro era composto por dois lugares, tinha apenas três rodas e podia alcançar a velocidade máxima de $13 \mathrm{~km} / \mathrm{h}$. (Figura 1 ). 


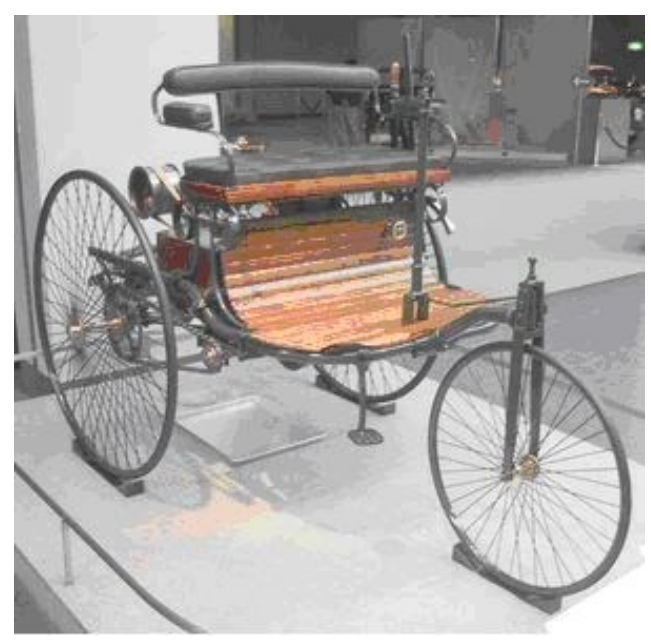

Figura 1: Primeiro carro movido à gasolina desenvolvido por Karl Benz

Fonte: História do Carro.com

Contudo, em 1908, Henry Ford lança nos Estados Unidos o primeiro carro mais parecido com o que temos hoje em dia: o Ford Modelo T Preto (Figura 2) e que custava na época U\$850. Por volta de 1927, Henry Ford suspende a produção pela saturação do mercado e percebe que é hora de um novo produto.

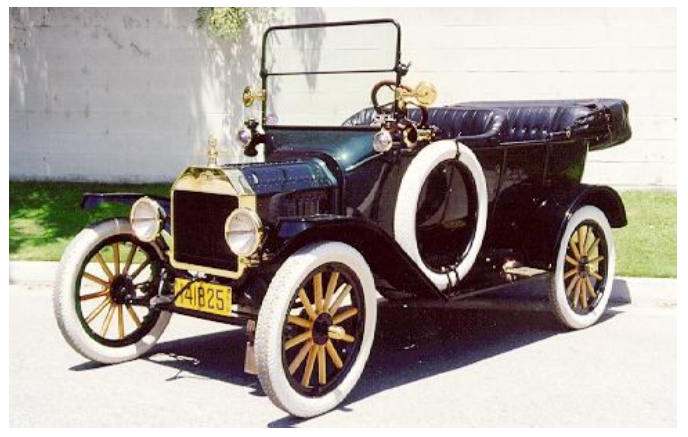

Figura 2: Ford Modelo T Preto

Fonte: Musclecarclub.com

Por volta de 1930, na Alemanha, segundo Kataoka (2008), surge um carro com conceito popular, um carro para o povo, inspirado no sucesso do Ford T. A idealização de um carro popular foi uma ideia estratégica, já que a Alemanha passava por um período de instabilidade econômica e política. Hitler assumia o poder e estava com o compromisso de melhorar a economia do país. Assim a ideia de um carro para o povo, feito por alemães, era a jogada ideal para concretizar seu objetivo e Ferdinand Porsche foi designado a realizar seu desejo.

Os primeiros modelos desenhados dos Fuscas não eram iguais aos que conhecemos hoje, não tinham quebra-vento, para-choques, as portas se abriam ao contrário dos de hoje e ,em 1936, o protótipo ganhou a carroceria com o 
desenho que o fez ficar conhecido pelo mundo inteiro. Em 1937, alguns modelos entraram em fases de testes e apenas em maio de 1938 aconteceu a grande inauguração para o povo. (Kataoka, 2008). (Figura 3)

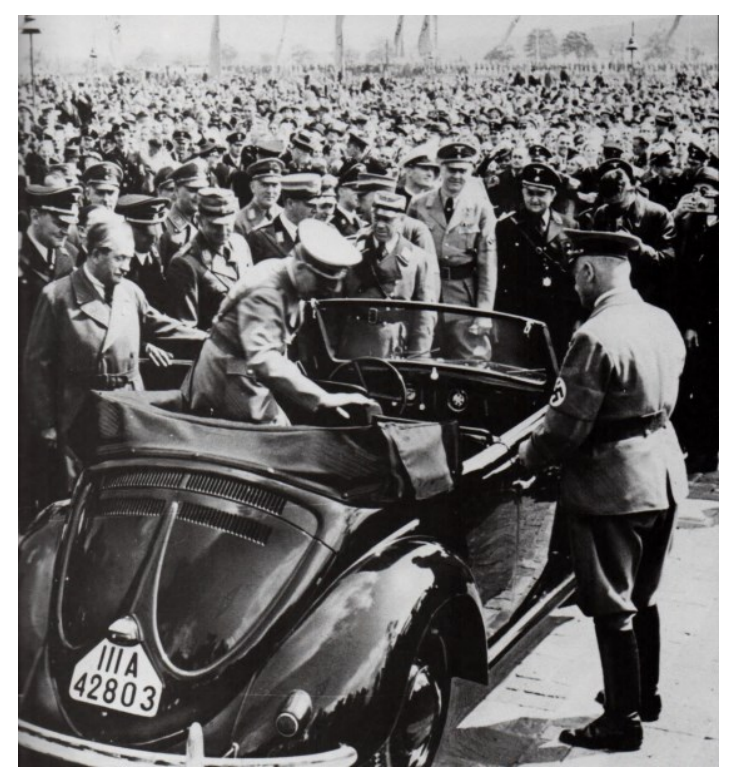

Figura 3: Hitler no lançamento do Fusca 1938

Fonte: Tokdehistoria.com.br

Com o início da Segunda Guerra Mundial em 1939, a Volkswagen produz Fuscas e derivados, como jipes e um carro anfíbio para serem enviados para a Guerra. Com a dificuldade de produção após a Segunda Guerra, começaram as primeiras exportações, sendo a primeira para a Holanda.

No Brasil o primeiro modelo de Fusca chegou em 1951 (Figura 4), mas foi em 1953 que a Volkswagen criou sua primeira fábrica em solo brasileiro. As peças vinham da Alemanha e, inicialmente, todos com motor $1.200 \mathrm{cc}$. Segundo Kataoka (2008), em seu primeiro ano de fabricação nacional, foram vendidas 8.406 unidades e, após 1962, já se comandava o mercado automobilístico brasileiro com 31.014 modelos vendidos. 


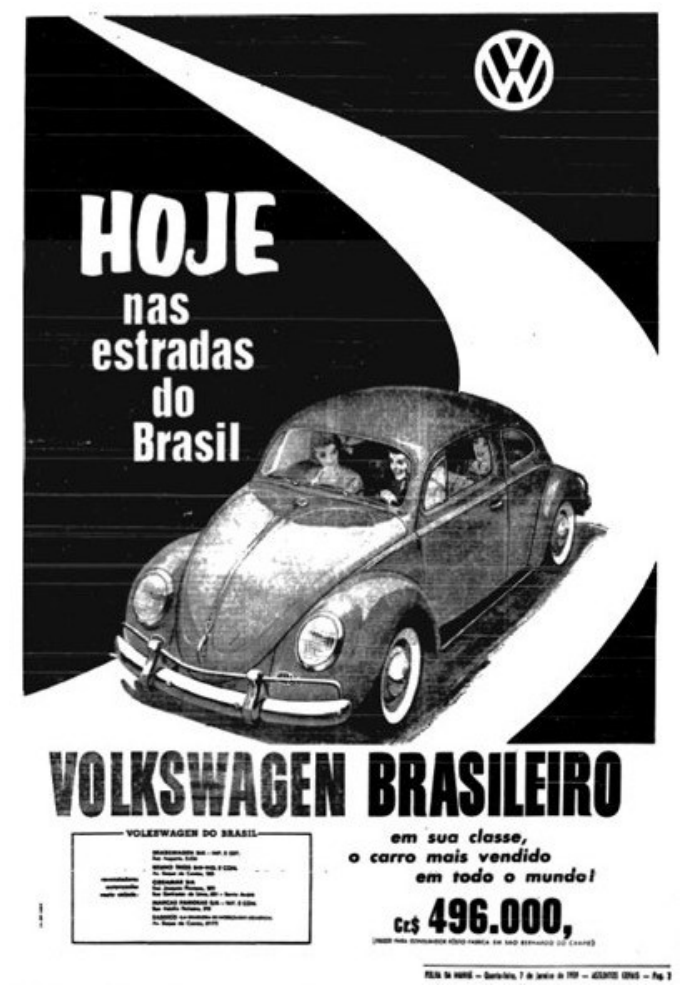

Figura 4: Primeiro anuncio do Fusca no Brasil 1951

Fonte: Caranddriverbrasil.uol.com.br

O nome Fusca não é o nome de batismo do carro. O nome dado na Alemanha era Volkswagen Sedan, porém pela dificuldade da pronuncia e pela tradução da abreviação de Volks para Folks, ao longo do tempo foi se adaptando para o que se conhece hoje como Fusca. Sendo assim, por volta de 1960, percebendo o apelo popular pela mudança de nome do Volkswagen Sedan, foi rebatizado como Fusca.

De acordo com Kataoka (2008), o Brasil, no início da década de 60, comandado por Juscelino Kubitscheck, investia fortemente em infraestrutura para desenvolvimento do país, com o seu programa 50 anos em 5 . Com isso o setor automobilístico ganhou espaço no Brasil e a renda obtida nesse setor logo ultrapassou a do café.

Ainda segundo Kataoka (2008), os anos de 1970 foram considerados a "era do Fusca no Brasil". Nesse período chegou a ser o carro mais vendido no mundo, passando o inovador Ford T. No Brasil, chegou a alcançar $40 \%$ das vendas nacionais de automóveis, aproximadamente 200.000 unidades vendidas. Devido a essa explosão de vendas no Brasil, a Volkswagen Brasil começa a exportar o Fusca para todo o mundo, chegando a apresentar uma fatia de $52 \%$ da Volkswagen Matriz. 
Porém, por volta de 1980, ainda segundo Kataoka (2008) o Fusca sofria pressão dos concorrentes. Percebendo a queda das vendas, os modelos Gol, Voyage, Parati e Saveiro são desenvolvidos pela Volkswagen, mas em 1983 acontece a primeira suspensão da produção de Fuscas.

Dez anos depois, em 1993, o Fusca retornou. Na época o então presidente do Brasil Itamar Franco trouxe de volta a produção do veículo, com a intenção de criar empregos, incentivar a produção de automóveis e retomar os tempos de glória do veículo, batizado então de "Fusca Itamar". (Figura 5). Estava evidente que o automóvel idealizado por Adolf Hitler já havia conquistado um lugar no coração do brasileiro.

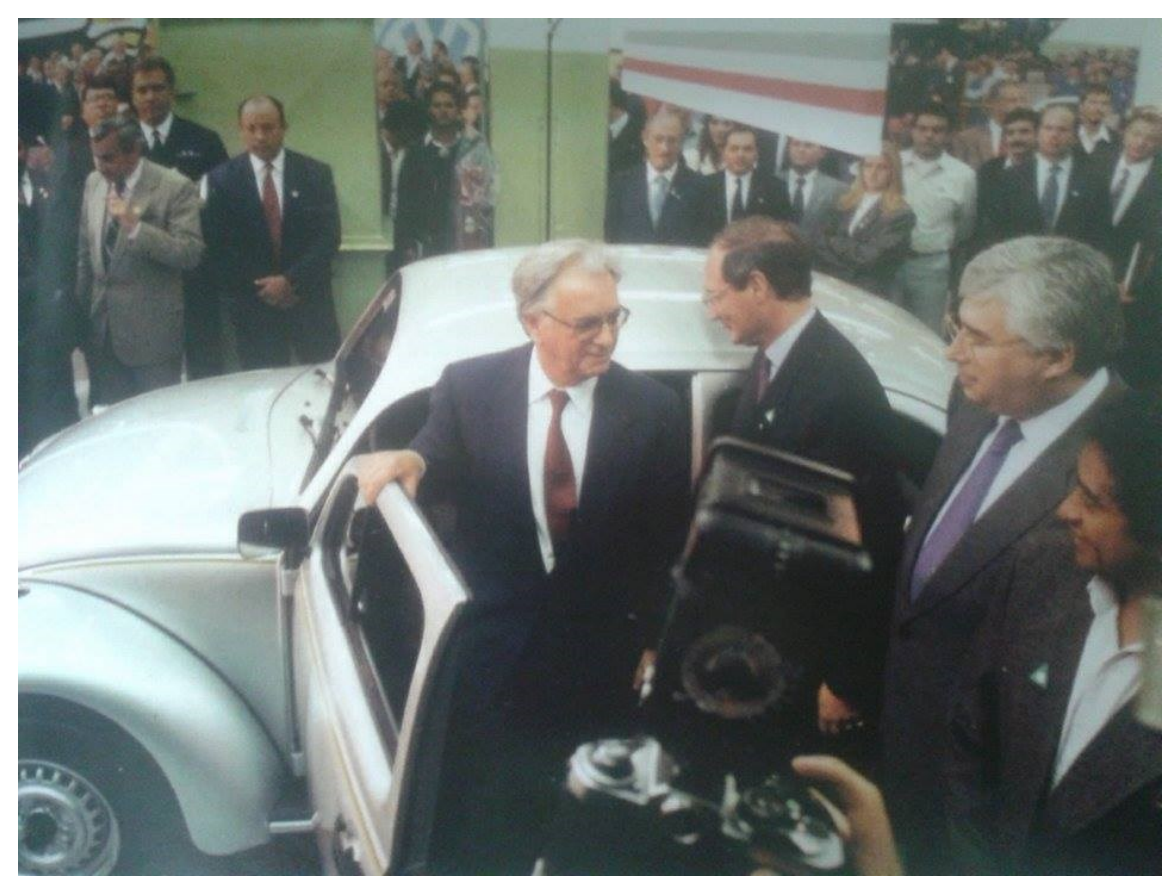

Figura 5: Itamar Franco no dia do relançamento.

Fonte: Fusca: Uma Paixão (2008)

A sua ultima produção foi no México em 2003 (Figura 6). Porém mesmo depois de muitos anos desde o seu desenvolvimento até o termino da sua fabricação e até os dias de hoje, é possível ver diversos Fuscas de diferentes cores e modelos percorrendo as estradas Brasil a dentro. O carro se popularizou de uma forma que no dia 20 de janeiro é comemorado o dia nacional do Fusca e dia 22 de junho é comemorado o dia mundial do Fusca. 


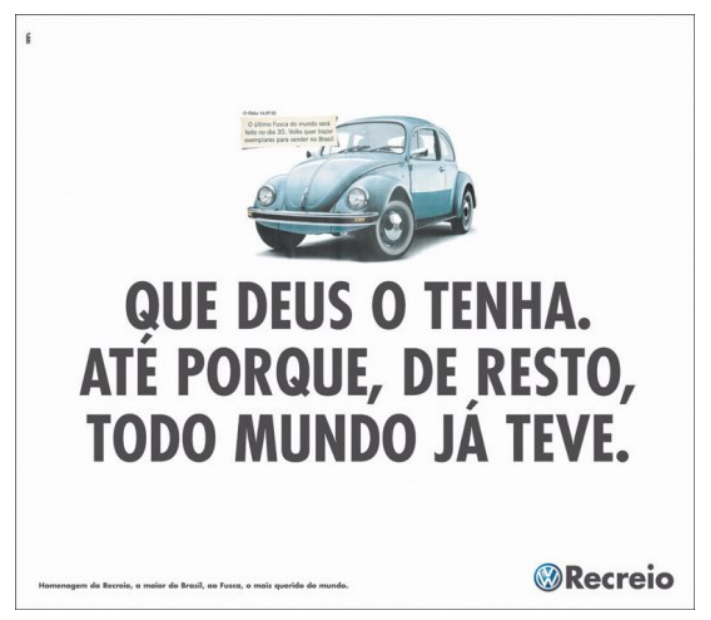

Figura 6: Anuncio da última produção de Fuscas no México

Fonte: Putasacada.com.br

O Fusca possivelmente ainda atrai milhares de admiradores ao redor do Brasil e do mundo. Existem clubes de Fuscas em diversas cidades do país como, por exemplo, o VW Clube do Rio de Janeiro, Fusca Clube do Brasil localizado em Indaiatuba-SP, Kafer Clube da Grande Florianópolis.

Diante desses fatos, cabe a seguinte pergunta: O que motiva uma pessoa comprar, restaurar e/ou manter um carro criado há mais de 60 anos?

\subsection{Objetivos do estudo}

Portanto, este estudo tem como objetivo final identificar os fatores que motivam as pessoas a comprar um Fusca, manter, ou apenas o fato de ter um carro desses em suas garagens.

Para se atingir o objetivo final proposto este estudo prevê alguns objetivos intermediários a serem alcançados:

$\checkmark$ Identificar quais são as características do carro mais valorizadas pelo consumidor.

Este objetivo pretende identificar quais os atributos que o consumidor considera mais importantes na hora da escolha da compra do Fusca, na hora de falar sobre o Fusca.

Apontar os hábitos e estilos de vida dos consumidores. 
Busca-se saber quais são os estilos de vida dos consumidores de Fusca, e saber se estes estilos tendem a ser semelhantes, ou se seguem alguma semelhança ou se são estilos distintos.

$\checkmark$ Identificar os valores que motivam os consumidores a comprarem o Fusca.

Pretende-se identificar quais valores motivam os consumidores a querer desejar ter um Fusca.

\subsection{Delimitação e foco do estudo}

Este estudo volta-se mais especificamente para abordar a questão de como se caracteriza a predominância do comportamento dos consumidores de Fuscas sob o ponto de vista específico de seus estilos de vida e, principalmente, os valores que os motivam estes consumidores a continuarem mantendo um carro que foi desenvolvido há mais de 60 anos atrás.

Tal ângulo de análise se mostra interessante e importante porque, embora seja um carro antigo, é possível que exista um número significativo de pessoas que adotam o Fusca não só como um carro, mas algo que vai, além disso, como um objeto sagrado e que tratam esse objeto como parte da família.

O estudo abordou 11 donos de Fuscas, todos moradores da cidade do Rio de Janeiro, com o intuito de captar, por meio de entrevistas em profundidade, suas percepções, emoções, memorias e opiniões relacionadas ao carro.

\subsection{Justificativa e relevância do estudo}

Os resultados alcançados também podem ser úteis para donos de lojas físicas e online de vendas de peças e acessórios, específicos para Fuscas, posto que com os resultados obtidos esses empresários vão poder conhecer melhor seus consumidores. À medida que a loja conhece melhor seu público, ela consegue saber os melhores meios de se conseguir uma aproximação mais 
eficiente com seus clientes e aplicar estratégias de forma correta, o que possivelmente aumentará suas vendas.

As informações que esse estudo produziu podem se mostrar de interesse para as pessoas que possuem um Fusca em suas garagens, pois o estudo é justamente entender o real motivo dessa paixão fervorosa pelo carro e assim os leitores e donos de Fuscas podem confirmar se se enquadram em alguma linha desse estudo.

Os gestores de marketing, publicitários e fabricantes de carro, podem aproveitar o resultado do estudo para auxiliar em um desenvolvimento de um novo produto, uma nova propaganda, publicidade e um novo carro, porque os resultados buscam entender o comportamento de consumidores de fuscas e que, possivelmente, são admiradoras de objetos antigos, ou que remetem a lembranças de outra época.

Outro público que também pode se beneficiar com o estudo feito, são os simpatizantes e admiradores de Fuscas que, embora sem nunca possuir um Fusca anteriormente, poderão despertar o desejo após se aprofundarem no assunto, descobrindo o sentimento de ter esse carro. Os resultados obtidos na pesquisa quanto ao estilo de vida dos donos de Fuscas pode ser um conhecimento a mais ou auxiliar em uma futura compra. 


\section{Revisão de literatura}

Neste capítulo são apresentados e discutidos aspectos conceituais e estudos relacionados ao tema e estudo em investigação e que servirão de base para a análise realizada. Esta seção está dividida em três partes e abordam, respectivamente, a questão do conceito de comportamento do consumidor, e em seguida os conceitos de cultura submersos no mundo do comportamento do consumidor. Na segunda seção discutem-se os conceitos de Estilo de Vida e as influencias que podem causar no consumo. Por fim na terceira e última seção deste capítulo apresenta as concepções de Nostalgia influenciando o consumidor.

\subsection{Comportamento do Consumidor e Cultura.}

O campo do comportamento do consumidor abrange uma ampla área: É o estudo dos processos envolvidos quando indivíduos ou grupos selecionam, compram, usam ou descartam produtos, serviços, ideias ou experiências para satisfazer necessidades e desejos. (SOLOMON, 2000). Outros autores como Schiffman e Kanuk (2000) definem o estudo do comportamento do consumidor, em o processo pelo qual o indivíduo decide gastar seus recursos ociosos como tempo, dinheiro, esforço, em produtos ligados a consumo. A área do estudo do comportamento do consumidor envolve procurar respostas para o que compram, por que compram, quando compram, onde compram, com que frequência compram e com que frequência usam o que compram.

Já segundo Churchill e Peter (2000), pesquisas sobre o comportamento do consumidor buscam entender o real motivo que leva os consumidores a comprarem determinados produtos e não outros. Para isso, profissionais de marketing estudam os sentimentos, os pensamentos e as ações dos consumidores e as influências sobre eles que determinam mudanças.

De acordo com Solomon (2000), conforme a sociedade evolui de uma cultura de massas, onde muitos consumidores compartilham das mesmas preferências, para uma cultura diversa, é de extrema importância identificar os diferentes segmentos de mercado e desenvolver mensagens e produtos 
especializados para esses grupos, que podem ser segmentados da seguinte forma: Faixa Etária; Género; Estrutura Familiar; Classe social e renda; Raça e etnia; Geografia; Estilos de Vida.

Quanto à faixa etária, pessoas de idades distintas tendem a não comprarem produtos ou serviços semelhantes. Quanto ao gênero, também, a tendência é que um produto direcionado para o público feminino, a princípio, não tem a intenção de atingir o público masculino. Quanto à estrutura familiar, o estado civil, e o número de pessoas na família podem ser possíveis fatores importantes para as empresas saberem direcionar seus produtos. Em relação à classe social, ela compõe um grande grupo de pessoas e as pessoas inseridas em determinadas classes tendem a ter gostos semelhantes em lazer, vestuário e músicas (Solomon, 2000). Em relação à geografia, a segmentação é dividida em áreas geográficas como estados, regiões, bairros. Por último, segmentação por estilos de vida também conhecida por psicografia é a segmentação baseada nos estilos de vida, atitudes, personalidades, interesses.

Essas definições sublinham o entendimento de que o comportamento do consumidor é muito mais que uma compra de um bem ou serviço e, sim, entender todos os conceitos internos dentro dos consumidores que levam eles a optar por determinado produto ou serviço ao invés de outro. Schiffman e Kanuk (2000) concordam afirmando que, para aprimorar o estudo da cultura, devem-se analisar todos os fatores ligados à sociedade como idioma, leis, religiões, hábitos alimentares, produto, música, arte, tecnologia e tudo que se refere àquele determinado grupo social. Segundo Kotler e Keller (2006), os fatores culturais são os que mais influenciam um consumidor.

Churchill e Peter (2000) ressaltam que o indivíduo é influenciado por vários grupos. Os mais importantes além de cultura, segundo Kotler e Keller (2006), são as subculturas e classes sociais, os grupos de referência e a família, que influenciam o comportamento do consumidor. De acordo com Solomon (2000), estas subculturas são grupos dentro de uma cultura cujos membros compartilham crenças e experiências comuns que os separam dos outros.

A cultura, segundo Solomon (2000), é vista como a personalidade de uma sociedade, contendo tanto elementos abstratos, como valores e éticas quanto elementos materiais como automóveis, vestuário, alimentos produzidos por uma sociedade. Em outras palavras "Cultura é a acumulação de significados, rituais, normas e tradições compartilhados entre os membros de uma organização ou sociedade" (SOLOMON, 2000, p. 568). 
De acordo com McCraken (2003, p.1) "O consumo é moldado, dirigido e constrangido em todos os seus aspectos por considerações culturais". Apesar disso, durante muito tempo a questão do consumo como um fenômeno de cultura não foi explorado em profundidade. A ligação entre cultura e consumo foi descoberta tardiamente pelas ciências sociais. Desde os anos 1980, ampliam-se os estudos que buscam entender os aspectos culturais implicados nas escolhas, preferências e hábitos dos consumidores. As motivações para gastar tempo e renda com determinados produtos e serviços são da ordem da cultura, como sugere McCraken (2003):

\footnotetext{
Os consumidores utilizam esse significado com propósitos totalmente culturais. Usam o significado dos bens de consumo para expressar categorias e princípios culturais, cultivar ideias, criar e sustentar estilos de vida, construir noções de si e criar (e sobreviver a) mudanças sócias. O consumo possui um caráter completamente cultural. (Mc Cracken, 2003, int.).
}

O objeto em estudo, o Fusca, se enquadra perfeitamente a passagem à cima, pois seu consumidor busca, através do carro, criar e sustentar um estilo de vida "retro". Mc Cracken (2003) aborda também o conceito de pátina, onde podemos utilizar o objeto de estudo, Fusca, como exemplo. O conceito consiste em uma confirmação material do status, uma confirmação visual, de posse do bem para afirmar que o individuo possui o status referente à classe. "A pátina é, em primeiro lugar, uma prioridade física e, somente então, uma prioridade simbólica das coisas. Esta the concede a real conexão com a coisa que ela significa." (Mc Cracken, 2003, 59).

\subsection{Estilos de Vida}

As opções de consumo de sociedades, as tradicionais não são de livre arbítrio como são as de sociedades modernas, mas sentenciadas pela classe, casta, aldeia ou família. Porém, nas sociedades modernas, a livre escolha de consumo quanto a produtos serviços e atividades define os consumidores e cria uma espécie de identidade social. A opção de escolha faz com que os consumidores manifestem suas características pessoais e estabeleça relações de identificação ou de distanciação com outras pessoas. (SOLOMON,2000) 
Solomon (2000) define estilo de vida como um padrão que o consumidor adota passar seu tempo disponível ao gastar seu dinheiro, fazendo o que the agradar mais. Segundo Kotler e Keller (2006), o padrão de vida é moldado através dos pensamentos, interesses e ações e representa a maneira pelo qual uma pessoa se relaciona com o meio no qual ela está inserida.

No sentido econômico, o estilo de vida representa o modo para se distribuir a renda, tanto em termos de diferentes produtos e serviços quanto de alternativas específicas nessas categorias (SOLOMON,2000). Assim temos os consumidores de Fuscas que optam por gastar sua renda reformando um carro antigo ao invés de utilizarem esse dinheiro em outro bem ou serviço. Nas figuras 7,8 e 9 vemos alguns exemplos de Fuscas reformados por consumidores que optaram por gastar tempo e dinheiro em um veículo antigo.

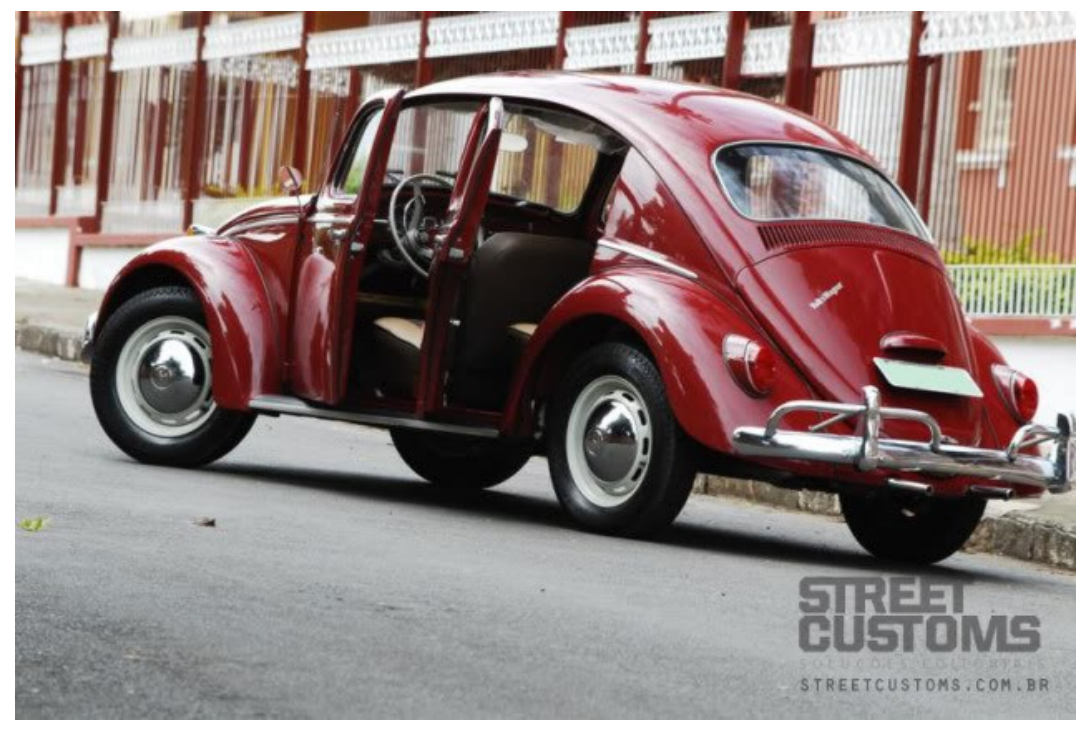

Figura 7: Fusca 1966 reformado com 4 portas.

Fonte: StreetCustoms.com.br 


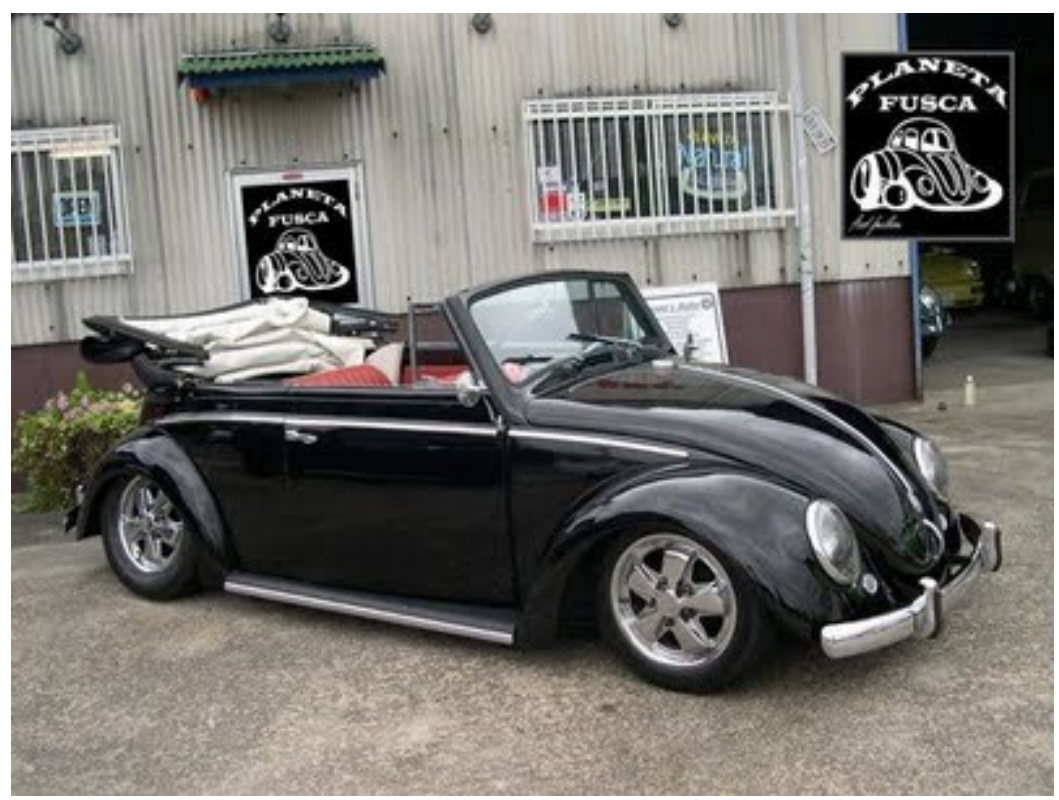

Figura 8: Fusca 1959 restaurado e conversível

Fonte: Simcarros.com

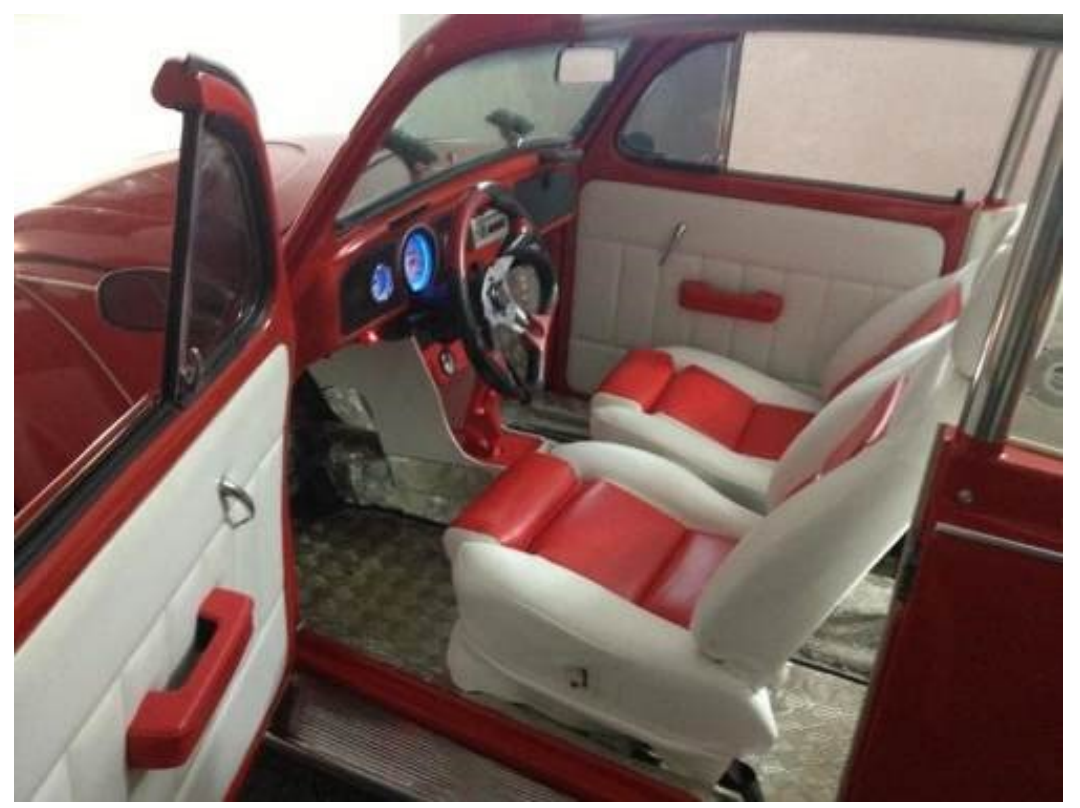

Figura 9: Fusca 1975 restaurado internamente.

Fonte: Preciolandia.com

Existem estratégias de marketing que utilizam o estilo de vida para atingir seu público alvo. De acordo com Solomon (2000), profissionais de marketing estudam sobre o estilo de vida relacionando o tempo e o dinheiro que o consumidor gasta para poder aproveitar e direcionar, da melhor forma possível, ações e produtos eficientes para esses consumidores. 
De acordo com McCraken (2003), para ter um melhor entendimento sobre as etapas de criação de um estilo de vida, ter clareza sobre o que chama de as "unidades Diderot" ajuda na realização desse estudo. McCracken (2003), sobre as unidades Diderot, propõe que os objetos possuem de alguma maneira uma complementariedade, ou seja, não quer dizer que um bem depende de outro, porém, um bem atrelado a outro completa o sentido.

É um conceito que pode ser bastante útil e eficiente, quando bem estruturados e trabalhados, para publicitários, com o objetivo de promover seus produtos e atrelá-los a um estilo de vida especifico. Utilizemos o objeto de estudo como exemplo, para o efeito Diderot, o Fusca. Trata-se de um veículo fora de linha, sem produção desde 2003, porém, mesmo assim, é possível ver diversos modelos circulando pelo país. Um dos objetivos deste estudo é justamente analisar o estilo de vida de pessoas que ainda mantém o carro em circulação. Supõe-se que os consumidores de Fusca sejam predominantemente pessoas do gênero masculino e com uma faixa de idade maior do que 50 anos. Voltando com o efeito Diderot, podemos supor que consumidores de Fuscas, de mais idades, recorrem a determinados produtos e serviços, optando por objetos similarmente antigos, ou "retrô", que de alguma forma associam a sua infância e juventude.

Um dos conceitos para compreender os estilos de vida foi baseado pelas unidades de Diderot. Segundo Mc Cracken (2003), o efeito funciona em três formas. A mais forte funciona impedindo que objetos não compatíveis com o significado cultural do todo seja imposto ao consumidor. A segunda, mais drástica, impõe o surgimento de uma nova união de produtos, isto é, a compra de um bem pode implicar em uma serie de compras subsequentes de forma a compor um conjunto coerente. A terceira forma, o consumo é definidamente trabalhado pelo consumidor, através de bens simbólicos (Fusca).

\subsection{Marketing de Nostalgia}

Nostalgia, segundo a Larousse Cultural (1995) é definida por melancolia, tristeza causada pela saudade da pátria, saudade do passado ou de algum lugar. Para Fleck, Abdala, Trott (2008), a nostalgia do ponto de vista atual é interpretada como um sentimento não patológico. Pode ser sentido por qualquer pessoa sendo assim conectado a um momento passado, um objeto íntimo antigo, ou um determinado jogo de outra época. 
Solomon (2000) afirma que nostalgia traz tanto sentimentos amargos, quando a emoção ligada ao passado é tristeza e saudade, quanto positivos, quando desperta de saudades com alegria dos bons momentos vividos antigamente. As experiências vividas anteriormente ajudam a definir o que apreciamos hoje. É trabalho do profissional de marketing utilizar de todos os conceitos possíveis para conseguir atingir o consumidor. Com isso estes profissionais revivem produtos, histórias e personagens do passado para tentar despertar o interesse dos consumidores de alguma forma. (SOLOMON, 2000).

Os produtos a qual optamos por comprar e usar reflete a extensão do nosso "eu", ou sobre o que pretendemos demostrar para a sociedade. Por isso o sentimento de nostalgia tem uma importância grande para o estudo do consumo, pois profissionais de marketing podem explorar certos sentimentos, imagens e ideias vinculadas ao tempo passado como forma de atingir nichos de consumidores. (Fleck, Abdala, Trott, 2008).

Abaixo alguns exemplos:

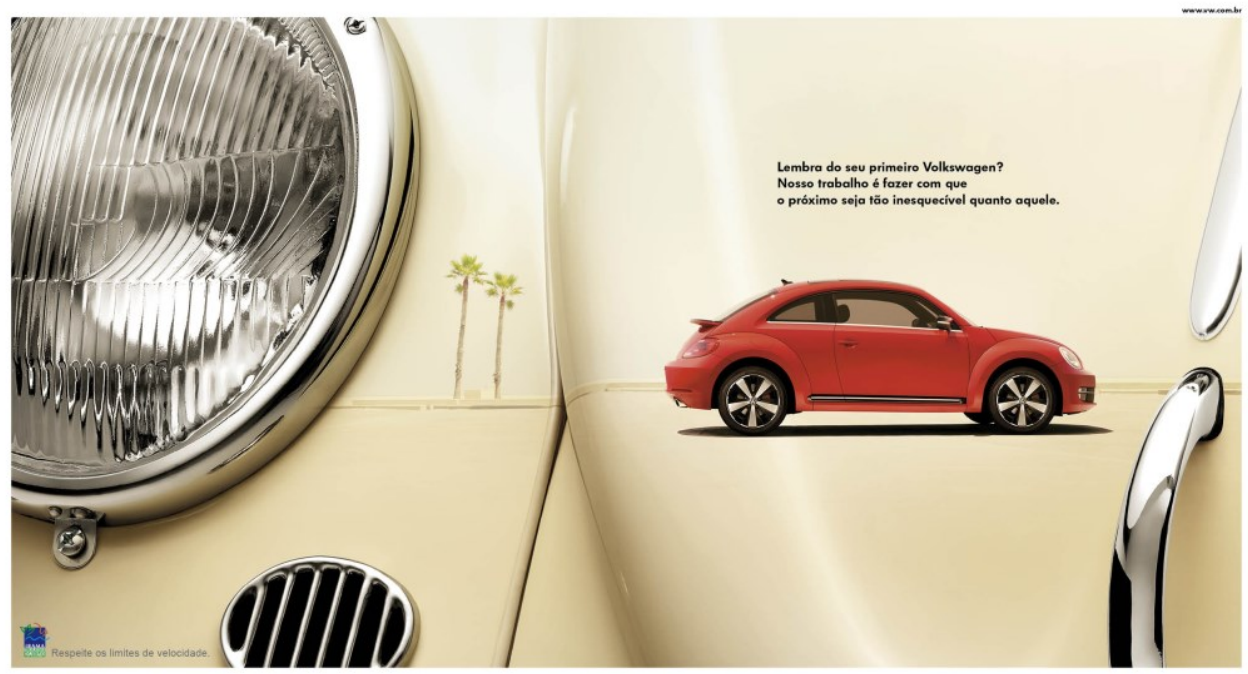

Figura 10: Anuncio do Novo Fusca sobre o antigo

"Lembra do seu primeiro Volkswagen"?

"Nosso trabalho e fazer com que o próximo seja tão inesquecível quanto"

Fonte: Br.groups.yahoo.com (2013) 


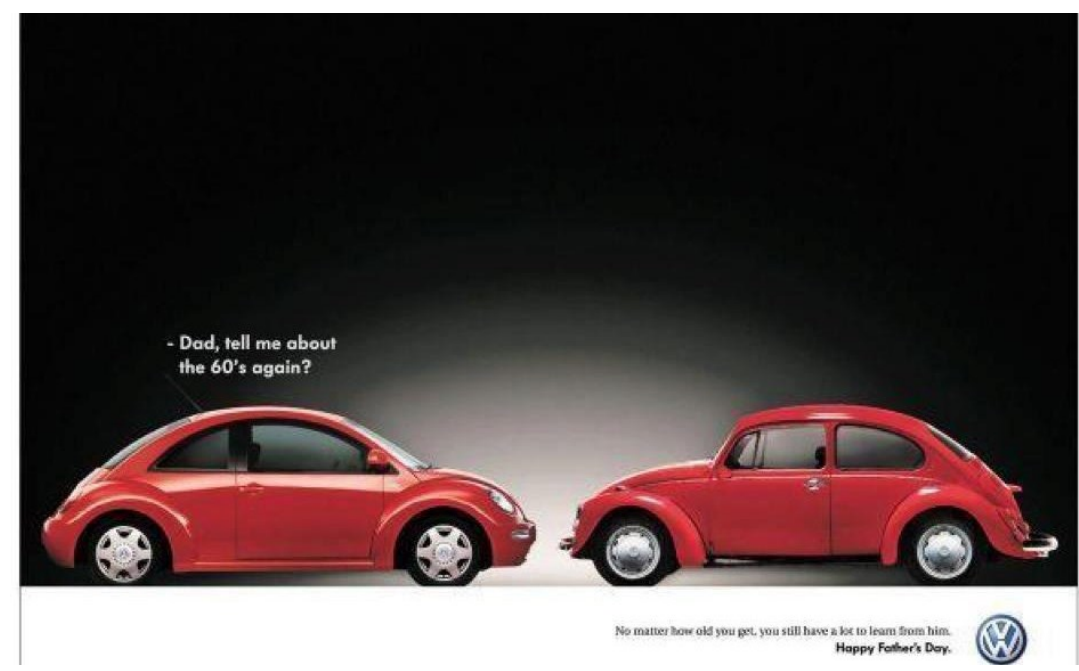

Figura 11: Outra do Fusca em comemoração ao dia dos pais

"Dad, tell me about the 60'S again?

Fonte: Brenobrito.files.wordpress.com (2012)

Outra empresa que apostou no relançamento de um carro antigo foi a Fiat, que em quatro de julho de 2007 lançou uma nova versão do Fiat 500. O relançamento aconteceu exatamente 50 anos após o lançamento da primeira versão do veículo, que foi em quatro de julho de 1957.

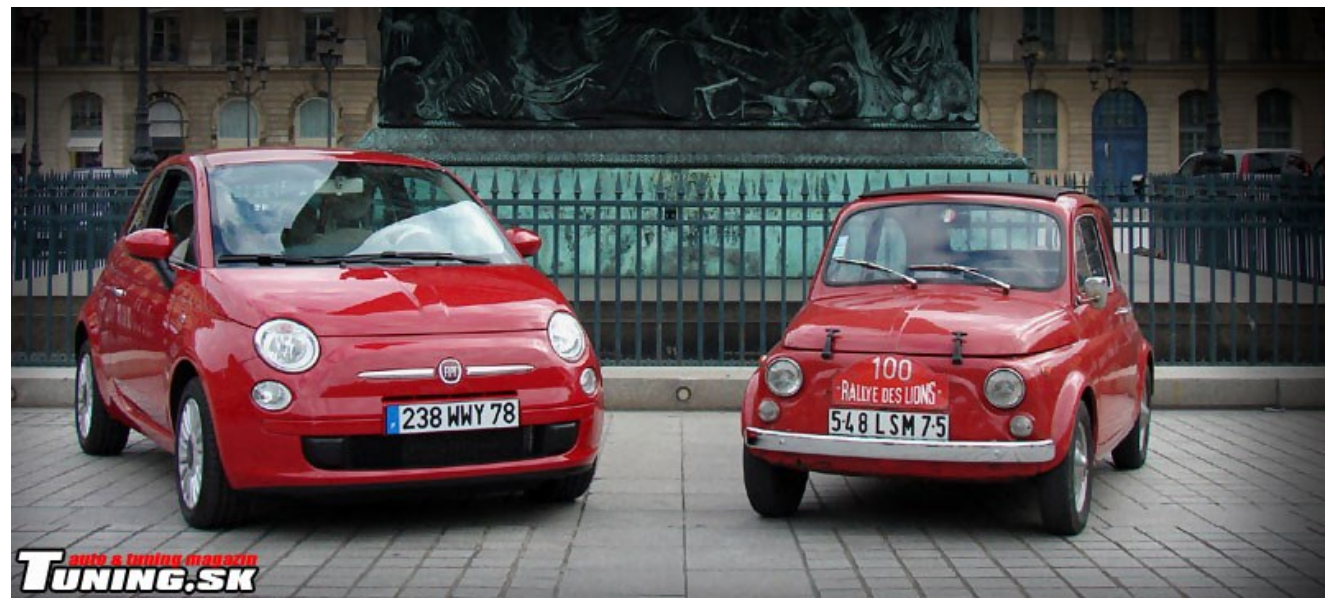

Figura 12: Versões do Fiat 500 (Novo x Antigo)

Fonte: Carrosnosangue.spaceblog.com.br (2011)

Segundo Exame (2013) cresce, entre os consumidores, o sentimento de nostalgia. Diversos itens lançados em tempos passados retornam as vitrines de lojas, para a alegria do público-alvo. 
A Brastemp, em 2011, adicionou ao seu portfólio de produtos um frigobar com curvas, linhas e características retros. A aceitação do produto foi boa e foi acrescentado um fogão e uma geladeira. (Figura 13)

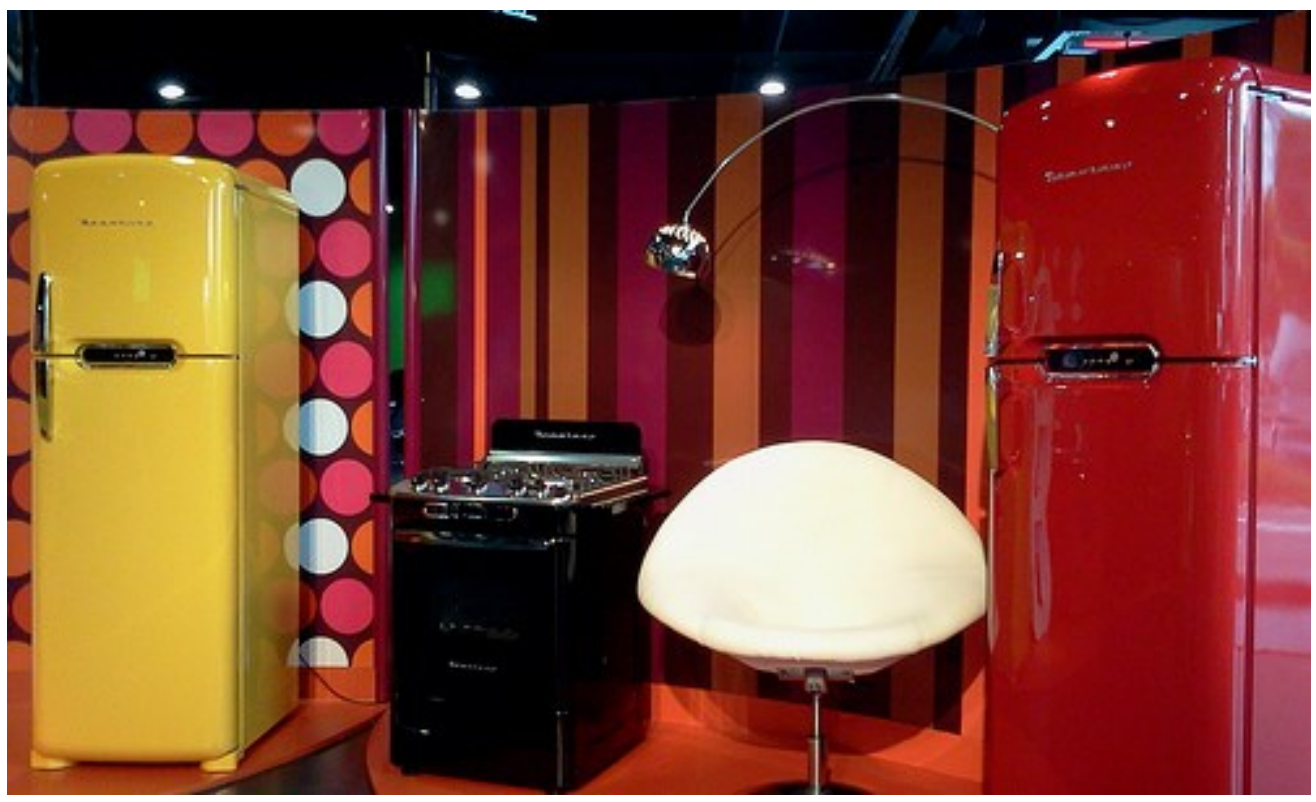

Figura 13: Brastemp lançando linhas de eletrodomésticos retro.

Fonte: Exame (08/2013; pág. 4)

Em 2012, o Lolo (Figura 14) chocolate referência nos anos de 1980, foi relançado pela Nestlé. A empresa recebeu diversos pedidos nostálgicos de consumidores para o retorno do chocolate. Foi realizado um acompanhamento pelas mídias sociais e uma análise do mercado. O chocolate foi relançado apenas no Brasil.

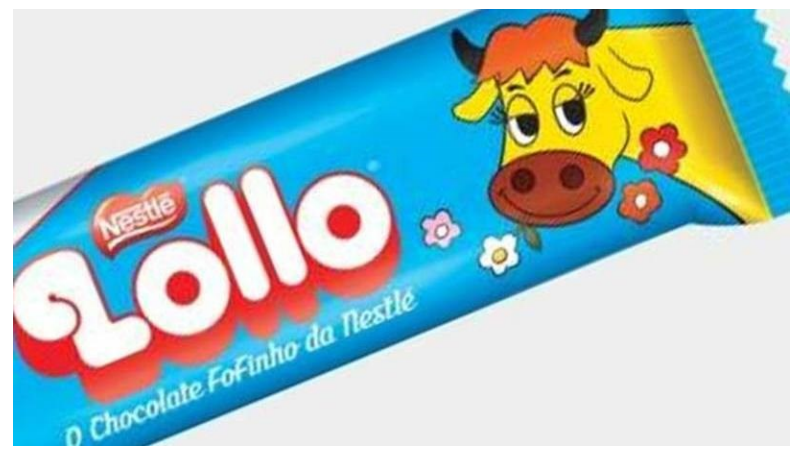

Figura 14: Chocolate Lolo

Fonte: Exame (08/2013; pág. 6)

Um último exemplo é o do Wafer Mirabel (Figura 15)I. A PEPSICO, empresa controladora da marca, realizou uma pesquisa de mercado com consumidores em todo o Brasil com o objetivo de reunir melhores lembranças 
em relação ao biscoito. Trinta anos depois, em 2012, a PEPSICO relançou o biscoito com a intenção de fazer com que os consumidores relembrem os bons momentos da infância.

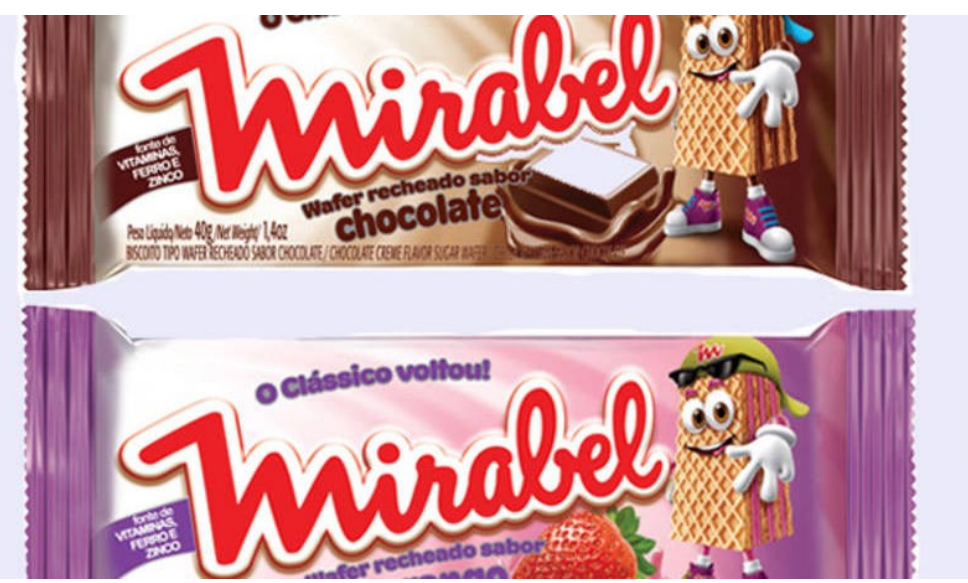

\section{Figura 15: Biscoito Mirabel}

Fonte: Exame (08/2013; pág. 5)

A nostalgia é um conceito importante para ser usado por profissionais de marketing, porque as lembranças ficam guardadas no inconsciente, adormecidas, esperando um momento para ressuscitar. Um objeto, um cheiro, um sabor, um lugar são exemplos de como reviver tempos passados e como poder atingir o consumidor através dos sentidos.

A nostalgia tem múltiplo efeito na experiência humana com reflexos na cognição, nas emoções, nas atitudes e também nas intenções de compra. No que tange à cognição, o autor sustenta que a nostalgia a afeta através dos processos de memória que são introjetadas através das experiências passadas. Com efeito, é a memória que dá corpo à experiência. (Mileto, Azevedo 2015 apud Marchegiani e Phau 2010).

A nostalgia é uma força importante para o mercado de consumo, pois utilizando essa ferramenta da maneira correta se torna mais fácil a aceitação de um produto pelo consumidor (SOUZA, POLIDORIO, 2013). 


\section{Métodos e procedimentos de coleta e de análise de dados do estudo}

Este capítulo irá informar sobre as diversas decisões a cerca da forma como este estudo foi realizado. Está dividido em três seções que informam, respectivamente, sobre as etapas de coleta de dados do estudo realizado, sobre as fontes de informação selecionadas para coleta de informações neste estudo. Na sequência, informa-se sobre os processos e instrumentos de coleta de dados realizados em cada etapa, com respectivas justificativas, sobre as formas escolhidas para tratar e analisa os dados coletados e, por fim, sobre as possíveis repercussões que as decisões sobre como realizar o estudo impuseram aos resultados assim obtidos.

\subsection{Estratégia de investigação ou Método de pesquisa utilizado}

Como primeira e única etapa, será realizada uma pesquisa qualitativa. $\mathrm{Na}$ pesquisa qualitativa, segundo Arilda Godoy (1995), o pesquisador vai a campo estudar o objeto de pesquisa em questão a partir das perspectivas das pessoas nele envolvidas, considerando todos os pontos de vista relevantes. Diversos tipos de dados são apurados e analisados para que se entenda a ocorrência do acontecimento.

Mais precisamente será realizada uma pesquisa exploratória para compreender o comportamento dos consumidores de Fuscas. A escolha de utilizar uma pesquisa exploratória foi tomada devido ao vago conhecimento sobre o assunto e, com a pesquisa, ela permite tomar um maior conhecimento antes de se concluir e afirmar qualquer fato. Desta forma, será elaborada uma pesquisa exploratória no formato de entrevistas em profundidade, conduzidas não pela forma de perguntas e sim de uma conversa, com um roteiro para certificar de que todos os assuntos importantes estão sendo abordados e, como uma conversa agradável, extrair todos os dados necessários para entender o comportamento do entrevistado perante o objeto. 


\subsection{Procedimentos e instrumentos de coleta de dados utilizados no estudo}

As fontes utilizadas são primárias devido ao conteúdo extraído das pessoas entrevistadas. Não serão utilizados dados secundários pela falta de textos relacionados ao comportamento de consumidores de Fuscas. Foi utilizado o método de entrevista em profundidade, pois é um assunto em que supostamente os entrevistados vão falar com a alegria e entusiasmo além de se tratar de um objeto em que eles possivelmente têm bastante carinho e afeição.

O número da amostra foi de 11 pessoas. Os entrevistados foram selecionados por proximidade e por indicação dos próprios participantes, todos possuem Fuscas. Os nomes dos entrevistados foram trocados por nomes fictícios por medidas de segurança:

\begin{tabular}{|c|c|c|c|}
\hline Nome & Idade & Profissão & Bairro \\
\hline Jorge & 44 & Contador & Tijuca \\
\hline Frederico & 28 & Engenheiro de Produção & São Conrado \\
\hline Paulo & 23 & Estudante & Jardim Botânico \\
\hline Jonas & 70 & Professor de Física & Gávea \\
\hline Otavio & 75 & Advogado & Recreio dos Bandeirantes \\
\hline Juan & 52 & Dentista & Barra da Tijuca \\
\hline Ricardo & 22 & Coordenador de Curso & Joá \\
\hline Gabriel & 54 & Desempregado & Barra da Tijuca \\
\hline Marcelo & 54 & Professor de Química & Jacarepaguá \\
\hline Francisca & 50 & Engenheira Ambiental & Barra da Tijuca \\
\hline Fabio & 24 & Ator & Jardim Botânico \\
\hline
\end{tabular}

Tabela 1: Descrição dos entrevistados

O autor foi ao $2^{\circ}$ Encontro anual Lord's de veículos antigos, ocorrido em 25/10/2015 no estacionamento do shopping Metropolitano, localizado na Barra da Tijuca, onde lá pôde observar o encontro com o objetivo de analisar o evento. No encontro, foram entrevistadas quatro pessoas. Todas as quatro entrevistas foram conduzidas durante o evento onde os donos estavam expondo seus Fuscas. O restante da amostra foi abordado: no campus da PUC-Rio onde entrevistei o professor da Física; no condomínio do autor, onde conversou com seu vizinho; na Praça do Ó localizada, no Jardim Oceânico, Barra da Tijuca, na praia da Joatinga, outra em sua residência, onde conversou com a tia do autor, e as duas últimas foram realizadas em um bar no Jardim Botânico, bairro onde moram dois entrevistados, o Fábio e o Paulo. 


\subsection{Formas de tratamento e análise dos dados coletados para o estudo}

A forma de tratamento escolhida para analisar os dados da entrevista será o método de análise de conteúdo. Foi adotado este método porque o investigador pretende identificar os motivos que levam uma pessoa a ter um Fusca.

A análise de conteúdo consiste em um conjunto de técnica de análise de comunicações que utiliza procedimentos ordenados de descrição do conteúdo das mensagens. Segundo CAMPOS (2004); a análise de conteúdo baseia-se em três fases sendo elas: (1) Pré-exploração; (2) Seleção das unidades de análise; (3) Processo de categorização e subcategorização.

A fase da pré-exploração, segundo CAMPOS (2004), é a fase inicial de leitura com a intenção de organizar e apreender aspectos importantes para as fases seguintes da análise. Estas leituras permitem ao investigador evidenciar a mensagem e, de uma forma menos elaborada, visualizar sinais e pistas não evidentes.

Já a seleção das unidades de análise é uma das mais básicas e importantes decisões que o pesquisador toma, porque consiste na escolha das partes analisadas, como palavras, sentenças, frases, parágrafos ou texto completo. As dificuldades nessa etapa e a justificativa da escolha entre uma parte, pois pode ser facilmente tendenciosa pela intuição do pesquisador.

Por último, continuando com o autor supracitado, o processo de categorização e subcategorização é o processo que se refere à seleção e classificação dos dados a serem analisados. As categorias podem ser: as apriorísticas, quando já se tem um conhecimento prévio, categorias pré-definidas sobre o tema; ou não apriorísticas, quando não se tem conhecimento prévio e dá mais trabalho ao pesquisador, pois é necessário um intenso diagnostico no material analisado.

Faz-se necessário, antes de começar a entrevista, explicar a finalidade da conversa e o real objetivo que o autor busca entender ao final de todo o trabalho, para fazer com que o entrevistado não omitisse nenhum fato que poderia complementar o estudo. Em todas as entrevistas o autor foi bem recebido, além de o fato do autor também ser um consumidor de Fuscas fez com que os entrevistados se sentissem à vontade em ter uma conversa aberta, falando toda 
sua história com relação ao Fusca e, às vezes, até perguntavam para o autor como ele se sentia em relação ao objeto, se mostrando interessados também pela história do autor. 


\section{Apresentação e análise dos resultados}

Este capítulo, organizado em uma seção, apresenta e discute os principais resultados alcançados com relação ao entendimento de como se dá e o que influencia a paixão dos entrevistados em relação ao Fusca.

Serão apresentados alguns dos comportamentos que foram possíveis de serem verificados a partir da entrevista realizada, com alguns trechos transcritos, que o autor considerou importantes para confirmar as hipóteses, além da análise com as referências bibliográficas descritas no capitulo dois.

\subsection{Resultado das entrevistas/Descrição e análise dos resultados}

Foram entrevistadas onze pessoas que são proprietárias de Fuscas, a fim de conhecer suas percepções, motivações e sensações sobre o fato de ter um Fusca. A amostra se dividiu em dez homens e apenas uma mulher. As idades variaram entre 22 e 75 anos. As entrevistas foram guiadas por um roteiro de perguntas, porém não ficaram presas a ele, e foram realizadas em ambientes informais com a finalidade de deixar o entrevistado à vontade para contar e relembrar suas histórias, fazer a conversa fluir de forma espontânea com a lembrança dos bons tempos que ele passou com seu Fusca.

A seguir apresento o perfil dos entrevistados destacando as partes mais interessantes sobre a conversa realizada.

O primeiro entrevistado foi o Ricardo, 22 anos, formado em Comunicação Social na PUC-Rio, coordenador de cursos na Perestroika e amigo pessoal do autor. A conversa com o Ricardo foi bem prazerosa, pois o contato que ele tem com o objeto Fusca é algo recente. Segundo ele, o primeiro contato que ele teve com um Fusca foi em um sábado de sol, há aproximadamente quatro anos, em que ele e mais quatro amigos foram para a Prainha surfar em um Fusca e o interessante era que esse Fusca era o do autor. Foi a primeira vez que ele andou em um Fusca e para Ricardo essa experiência foi bem marcante. Há dois anos, ele tinha juntado um dinheiro e sentia a necessidade de comprar seu primeiro carro, por morar no bairro do Joá, bairro de difícil acesso, com apenas duas linhas de ônibus passando pelo bairro. Decidiu comprar um fusca, um 
vermelho, ano 1995. Mesmo sendo um consumidor recente, Ricardo já demonstra um carinho e um afeto grande pelo o carro. Segundo ele, o Fusca fala sobre a pessoa e só o fato de ele ter um Fusca demonstra certa humildade, coisa que valoriza bastante. O Fusca representa seu estilo de vida. Ricardo mora com a família e em casa possuem três carros contando com o Fusca. Mas o Fusca é dele e utiliza para tudo que precisa: trabalho, lazer e é no trabalho principalmente, onde todos adoram o carro. Segundo ele, o Fusca é ideal para o rumo que ele resolveu seguir na vida. Para Ricardo, as características mais fortes do veículo são o design, a simplicidade, a funcionalidade e de novo cita a humildade. Quanto a pontos negativos, ele comenta que o ponto negativo do Fusca é ele, pois não tendo dinheiro para uma manutenção, acaba não dando a atenção necessária para o carro funcionar em perfeitas condições. Mas afirma que, com tempo e dinheiro, não tem ponto negativo. Ricardo não deu apelido para o Fusca embora acredite que mereça um, pois segundo ele o carro tem personalidade, ele leva uma carga emocional e garante que ainda vai batizá-lo.

"Acho que o carro fala muito da pessoa e eu acho que ele fala bastante sobre a minha pessoa; o Fusca representa meu estilo de vida e mesmo estando pouco tempo com ele já pude pegar uma afeição muito grande (...). Ao mesmo tempo em que ele é um carro antigo, ele é um carro atual."

A segunda entrevista foi com a tia do autor, Francisca, 50 anos, formada em engenharia ambiental. O primeiro contato com o Fusca de Francisca foi quando o pai dela comprou o primeiro Fusca; é a primeira coisa que se lembra. Francisca sempre gostou do carro, pois o Fusca, para ela, lembra a família, que não era pequena, e lembra as viagens que faziam juntos. Lembra também o ano de 1970, que foi uma época muito boa em sua vida. Ela conta que há uns dez anos comentou com o marido sobre Fusca e contou um pouco da infância. Até que um belo dia, o marido chega com uma surpresa: um Fusca 1985 vermelho, motor 1,5 e apelidado carinhosamente de Tomatinho. $O$ relacionamento dela em relação ao Fusca se resume, segundo ela em xodó, sensação de prazer, nostalgia, amor e afirma que a característica mais forte do veículo é o barulho. Francisca possui três carros além do Fusca e o dirige duas vezes por semana mais ou menos, dando uma volta pela cidade. Francisca conta que esses dez anos ao lado do Tomatinho foram muito bem vividos, com a manutenção em dia, 
não deu nenhum problema. Finalizando Francisca resume em Liberdade o fato de possuir o Fusca.

"O Fusca me lembra muito dos meus pais, e nossas viagens para visitar nossos avos, nos éramos cinco irmãos e viajávamos nos cinco no banco de trás, além de levar um galo e uma sanfona e ninguém reclamava"

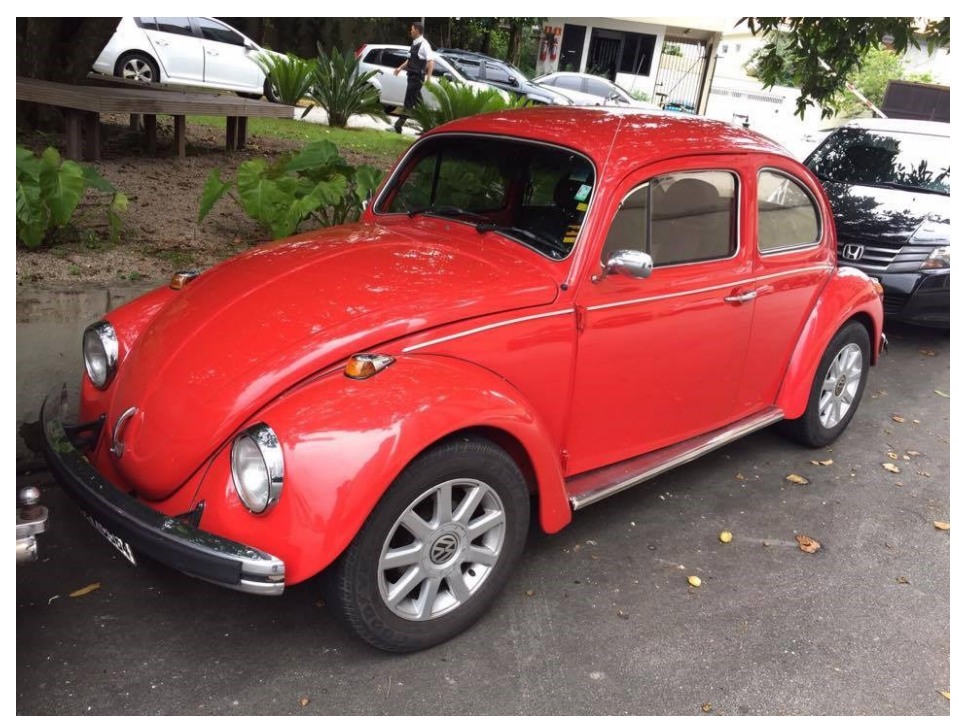

\section{Figura 16: Tomatinho da Francisca}

Fonte: Arquivo pessoal da entrevistada

A terceira entrevista foi com Juan, 52 anos, dentista e morador da Barra da Tijuca. Juan é dono de três Fuscas atualmente: Pirulito, um Fusca azul e branco de ano 1968, motor 1.3; Bulldog, um de ano 1975, motor 1.5; e um sem apelido, Fusca Itamar (como foi batizado quando o então presidente do Brasil trouxe de volta a produção de Fuscas no Brasil), ano 1993. O primeiro contato de Juan com o Fusca foi o carro que aprendeu a dirigir, que segundo ele foi um Fusca 79, primeiro carro a álcool do Brasil. Ficou com ele quatro anos. Há aproximadamente quinze anos, Juan decidiu que queria porque queria comprar um Fusca e, andando pelo Rio de Janeiro, viu um Fusca com placa de "vendo" e comprou o Pirulito. Dois anos depois, comprou o Bulldog de um porteiro de um prédio perto do seu e três atrás comprou o Itamar, de uma vizinha da irmã. Para Juan, a palavra Fusca lembra os bons momentos de sua vida, uma época boa de viver, além de lembrar uma época glamorosa que o Brasil passou, tempos bens diferentes do que se vê hoje, e logo sua relação com o carro é de nostalgia pura segundo ele, que dirige em média três vezes por semana, alternando os Fuscas, seja indo para o trabalho, seja alguma outra ocasião. Juan comenta as 
características mais fortes do carro sendo a durabilidade, a simplicidade do projeto e a eficiência. Como ponto negativo, o fato de não ter um arcondicionado. Em relação à família, Juan conta uma história engraçada. Ele é divorciado e mora com as duas filhas, e que antigamente elas tinham vergonha do Fusca, não queriam ir para escola com ele de jeito nenhum. Hoje em dia é uma briga entre as duas decidindo qual fica com qual. Uma das histórias marcantes que Juan conta aconteceu com o seu primeiro carro, o 79 a álcool. Era época em que os postos fechavam final de semana e que precisava sair, porém, estava sem combustível. Até que um amigo do pai falou que o álcool brasileiro era de uma qualidade tão ruim que, se ele colocasse álcool de cozinha, álcool hidratado, o carro pegava e assim aconteceu. E contando uma situação embaraçosa, conta que, com esse mesmo Fusca 79, motor a álcool estava dando problemas constantemente e certo dia foi a um mecânico e perguntou se Ihe interessava o motor e se não trocava por um a gasolina; assim fez, o carro passou a andar normalmente sem dar problemas, porém Juan fez sem o consentimento do pai. Quando seu pai foi trocar o veículo dando ele de entrada, deu problema na papelada, seu pai descobriu e desistiu de dar outro carro para Juan. Hoje em dia, Juan conta que a mecânica de seus três Fuscas acontece mensalmente, com um velhinho, seu João, mecânico morador do terreirão (favela localizada no Recreio dos Bandeirantes), e que, segundo Juan, reconhece o problema pelo barulho que o Fusca está fazendo. Juan conta que, como toda máquina antiga, precisa de manutenção constante e precisa ser ligada, e diz que se andar com o Fusca todos os dias ele não dá problema. Juan encerra a entrevista resumindo em prazer inenarrável o fato de ter os Fuscas, e que não tem coisa mais prazerosa do que sair de Fusca aos finais de semana com a camisa do Bangu.

"A minha relação com o meu fusca é de nostalgia pura, ele me lembra dos grandes bons momentos da minha vida e eu tive fusca em grande parte da minha vida (...) Ter um fusca é um prazer inenarrável." 


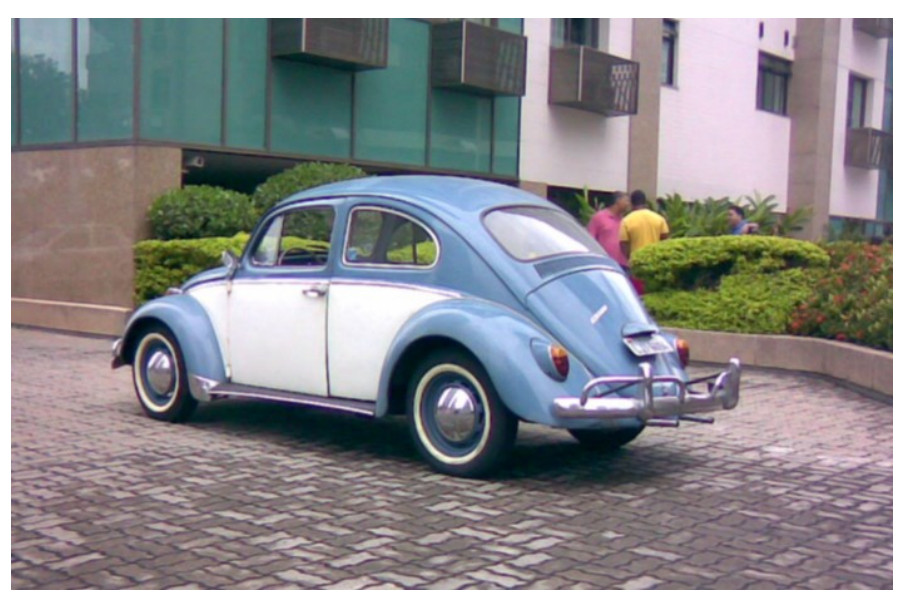

Figura 17: Fusca Pirulito ano 1968

Fonte: Arquivo pessoal do entrevistado

A quarta entrevista foi com o Jonas, 70 anos, e professor da Física da PUC Rio há 45 anos. Jonas teve seu primeiro contato com o Fusca e assim como o Juan, foi o carro em que aprendeu a dirigir, por volta do ano de 1960. Conta que o Fusca era o carro do momento, carro mais popular do país, barato e feito no Brasil, era sensação e que todos os jovens queriam ter um Fusca. Jonas conta que já teve quatro Fuscas, de acordo com ele o primeiro foi algo como 62, o segundo foi um 66, o terceiro foi um 68 e o quarto, que é o atual, é de ano 72, amarelo, está com ele há 33 anos. Comprou em 1982 de segunda mão de uma vizinha, que tinha adquirido cinco anos antes e que não tinha $5.000 \mathrm{~km}$ rodados. Hoje, segundo ele, já tem mais de $500.000 \mathrm{~km}$ rodados. E a palavra Fusca representa para Jonas o carro da vida dele, apesar de ter outro mais moderno, para viagens. Foi o Fusca 72, amarelo, que é presente em boa parte de sua vida, é mais velho que todos os três filhos, e conta que todos os três filhos nasceram no Fusca, no sentido de ter levado a mulher no hospital e trazer de volta para casa. Ele menciona as inúmeras viagens que fez com a família e amigos. A mais marcante foi em 1966, tinha acabado de se formar na PUC e foi de Fusca para Brasília com um amigo boliviano da faculdade. Outra história marcante que Jonas contou foi quando foi para o extremo sul do país com seu primo, que também tinha um Fusca. Eles turbinaram os dois Fuscas em um só, retiraram o que tinha de melhor em um e colocaram em outro, e assim seguiram viagem e conta que a capacidade do Fusca em andar em terrenos alagados, terra, é melhor do que carros mais modernos, que é uma das características mais fortes do carro, segundo ele. Mas, a mais importante é o barulho que o veículo faz, as pessoas sabem que você está chegando de longe. Uma história 
curiosa do Fusca em relação à família é que, quando seus filhos eram pequenos, perguntavam se iam para escola de Fusca ou de carro, e conta que os filhos pediam para parar um quarteirão antes da escola para que amigos não os vissem saindo do Fusca. Jonas conta que, quando se tem um carro há 30 anos, acaba conhecendo os problemas e que a mecânica é simples. Problemas aparecem de tempos em tempos, mas são fáceis de resolver. A única modificação que ele fez no carro foi diminuir o volante, pois Jonas é alto e conta que tinha dificuldade de entrar no carro. De resto, manteve tudo igual, até o radio é original, porém, não funciona. Ele fala da insegurança que é o Rio de Janeiro com carros e para precaver um roubo preferiu não arrumar o som. Jonas conta sorrindo, que é frequente velhinhas lhe pararem achando que estão chamando taxi.

"Não dá para resumir em uma palavra, mas em várias como um membro da família, ele é mais velho que meus filhos, todos cresceram nele. Quando eu entro nele é uma sensação de velho amigo, velho conhecido, eu sei os problemas dele e ele provavelmente conhece os meus, sentimento de parceria, cumplicidade."

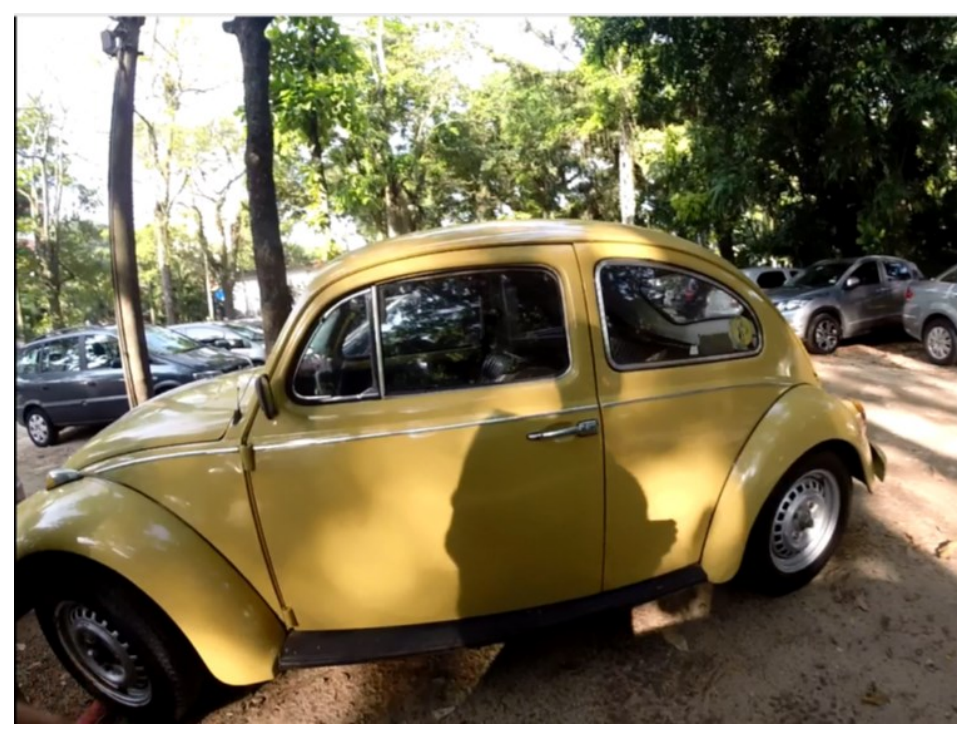

Figura 18: Fusca 72 do Jonas

Fonte: Autor

A quinta entrevista foi com o Frederico, 29 anos, engenheiro de produção, amigo pessoal do autor e trabalha com bio-construção. Frederico conta que seu primeiro contato com o Fusca foi ainda bem pequeno, com 14 anos. O carro de 
seu pai quebrou e um vizinho emprestou o Fusca dele para a família e eles ficaram com ele um bom tempo. Os tempos passaram e Frederico conta que sempre gostou do design do carro, na escola desenhava Fusca com pranchas em cima e falava para si mesmo que um dia iria comprar um Fusca e iria surfar com ele, era um sonho. $E$ há cinco anos Frederico realizou seu sonho, tinha guardado um dinheiro e estava à procura, conta que comentava sua paixão com colegas de trabalho e um dia um amigo indicou um vendendo, um Fusca branco de ano 73, comprou de segundo dono, o carro estava todo original e assim ele manteve, retirando apenas o platinado. O relacionamento inicialmente era um relacionamento difícil, conta ele. Frederico ainda estava aprendendo a mecânica e era constantemente sendo rebocado, mas com o passar do tempo foi melhorando, foi ajustando e ultimamente conta que está muito feliz com o carro e o sonho está realizado, pois vai surfar com o Fusca constantemente. Em relação a como é visto seu comportamento com o Fusca perante amigos e família, Frederico conta que alguns o chamam de louco de, ficar gastando dinheiro em um carro antigo que sempre dá problemas, mas ele conta que as pessoas não entendem, e só quem tem a paixão realmente entende o motivo de cuidar, manter o Fusca. Frederico hoje possui, além do Fusca, uma Kombi, qual a trouxe do sul do Brasil, de Rio Grande, extremo sul do Rio Grande do Sul, aonde veio até o Rio de Janeiro pela costa surfando. Frederico conta que o que o atrai no Fusca é o design, a beleza que o carro transmite a unicidade, a exclusividade, e cita também a humildade assim como o primeiro entrevistado Ricardo. E, como ponto negativo, ele cita em relação à mecânica, mas de novo fala como outros entrevistados que, se tiver um cuidado constante ele anda sem problemas. Uma história marcante, conta Frederico, foi saindo de uma boate com uma menina, e quando estavam indo para o carro, ele pergunta a ela, advinha qual é meu carro, é o mais novo da rua? E ela lhe responde, duvido que você tenha um Fusca, ele fala: muito irado né? Ela: se o Fusca for realmente seu eu não vou embora com você, achei que você fosse playboy. Resumindo, ele conta que entrou no carro, deixou-a na rua e foi embora e acrescenta que o Fusca o fez não perder tempo com uma menina que não valia a pena. Fechando a entrevista, Frederico resume em sonho realizado o fato de ter o fuca, apelido que deu para seu carro, em sua posse. 
"Desde 14 anos eu já falava que meu primeiro carro seria um Fusca, já desenhava o Fusquinha com as pranchas em cima (..) Comprar o Fusca, primeiramente, foi um sonho realizado e depois um companheiro de aventuras, aventuras que só poderiam ter acontecido com ele, uns perrengues que só ele poderia me proporcionar e que eu não vou esquecer nunca."

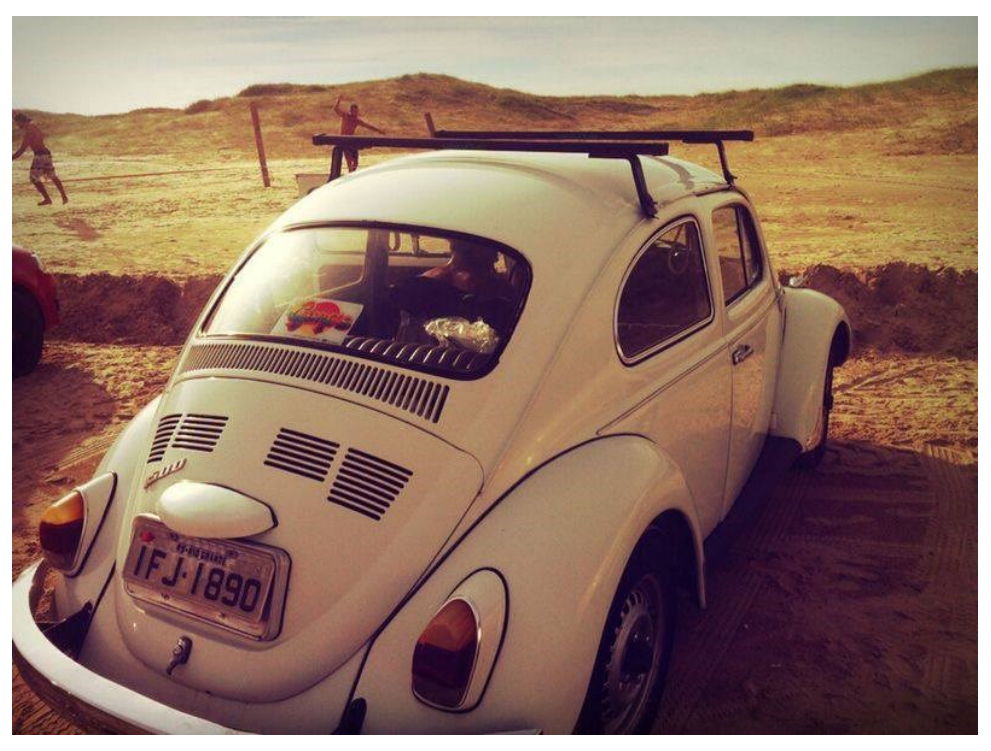

Figura 19: Fusca 1973 do Frederico.

Fonte: Arquivo pessoal do entrevistado

A sexta entrevista foi com o Fábio, 25 anos, ator e amigo pessoal do autor. Seu primeiro contato com o Fusca foi quando tinha 15 anos, em seu sítio, em Teresópolis, e seu caseiro tinha um Fusca e colocou-o para dirigir. Foi sua primeira experiência com direção e ficou marcado. Quando tirou a carteira, há três anos, tinha um dinheiro guardado e morava em Santa Tereza, bairro do Rio de Janeiro onde tem bastantes ladeiras e as ruas são a maioria de paralelepípedos e o Fusca atendia todas as suas necessidades e comprou um Fusca, ano 74, através do site bomnegócio.com. Fábio conta que Fusca para ele representa paz, surfar com os amigos, música, representa felicidade e que todo o dinheiro que ele ganha ele deposita no Fubika, apelido do Fusca. Fábio fala que comprou o carro por um preço bem baixo e por isso não estava nas melhores condições e fala que o relacionamento com o carro inicialmente era complicado e conta que uns cinco meses com o carro, no viaduto Lagoa-Barra ele simplesmente parou e ficou uma hora e meia parado, causando um engarrafamento enorme, até que uma boa alma o ajudou e era apenas uma 
peça que ele não sabia que estava fora do lugar. Desde então, ele conta que procurou a entender um pouco mais sobre a mecânica e comentou que existe um canal no YouTube de um cara chamado Marcelo Tonella, que possui 117.000 inscritos, em que ele explica, passo a passo, como mexer em diversas partes do Fusca, parte mecânica, parte elétrica, pinturas. Em relação à família e amigos, Fábio conta que a mãe odeia, pois acha que não é seguro o bastante, já o pai adora, sempre fazem passeios, os amigos adoram principalmente quando vão surfar e já alguns assim como o Frederico, o chamam de louco, por gastar dinheiro á toa, mas Fábio conta que vira um brinquedo de gente grande vira mais que um carro. Ele conta que o que mais o atrai é o design abaulado do Fusca, além do motor forte, aguentando qualquer tipo de terreno e quando bem regulado é econômico. Quanto a ponto negativo ele não cita nenhum pois, segundo ele, para a época que estamos não tem como colocar defeito. Finalizando, Fábio resume, assim como alguns outros entrevistados, em "Liberdade" o fato de ter o Fubika com ele, pois é quando ele realiza tudo e principalmente o que mais gosta de fazer que é surfar.

"Fusca me remete à paz, música, me remete a surfar com meus amigos e à felicidade. Todo o dinheiro que eu ganho eu ponho nele, por que é ele que me leva para me divertir, para fazer as coisas que me dão prazer."

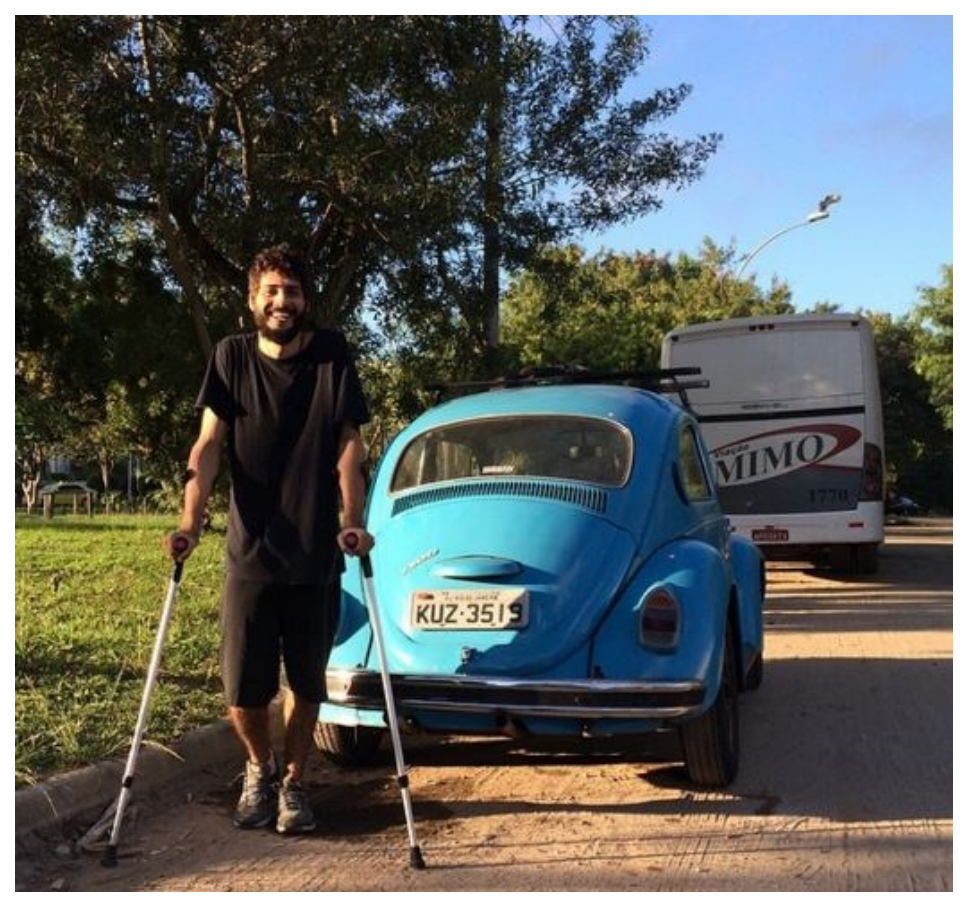

Figura 20: Fábio e o Fubika ano 1974

Fonte: Arquivo pessoal do entrevistado 
A sétima entrevista foi com Paulo, 23 anos, estudante e foi uma indicação do primeiro entrevistado Ricardo. O primeiro contato com Fusca de Paulo foi no sítio em que o avô morava em Nova Friburgo, Rio de Janeiro, onde ele tinha dois Fusca. Paulo conta que é tradição na família aprender a dirigir quando se completa 10 anos e foi o que aconteceu com o pai, tio, irmãos, primos e com ele. Quando seu avô faleceu, Paulo herdou um Fusca de ano 1973 azul, e está com ele há cinco anos. Paulo conta que o Fusca representa os momentos no sítio com a família, a nostalgia, a saudades do avô e o primeiro contato com a direção que algo que adora. Ele fala que a relação é total de carinho e afeição e que a família toda tem um carinho especial, pois tem uma ligação direta com o patriarca da família e que a maioria dos amigos adoram. Paulo dirige aos finais de semana e conta que é muito mais pelo lazer e prazer de dirigi-lo do que como meio de transporte efetivo. Quanto a características mais fortes, Paulo cita os fáceis "gatilhos" de manutenção, além de ser um carro forte, cita a unicidade e o companheirismo. Paulo contou que já passou por embaraços com o Fusca, mas o mais marcante foi indo para a praia em Ipanema e ele apagou a duas quadras da garagem onde normalmente para, duas viaturas da policia militar do estado do Rio de Janeiro estavam atrás dele buzinando, causando um engarrafamento até que segundo ele falou as palavras "Me ajuda, por favor! " E o carro ligou e seguiu seu caminho. Paulo finaliza resumindo em prazer em dirigir, ter o Fusca herdado de seu avô.

"O prazer que o Fusca me proporciona quando vou dar uma volta com ele, é um prazer único, as lembranças que ele me remete: da família reunida no sitio, as saudades daquela época e do meu avô, o carro é parte da família."

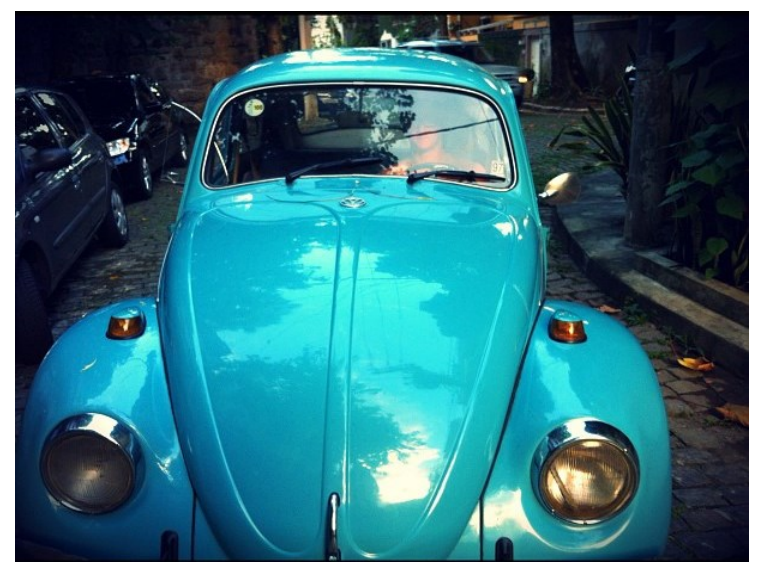

Figura 21: Ricardo em seu Fusca 73

Fonte: Arquivo pessoal do entrevistado 
A oitava entrevista foi com Gabriel, 54 anos e atualmente desempregado. Gabriel foi a primeira entrevista realizada no $2^{\circ}$ Encontro Anual Lord's de Veículos Antigos. Gabriel conta que seu primeiro contato com o Fusca foi na adolescência, quando tinha 20 anos comprou um Fusca 75, bege, de um amigo. Com o passar dos anos a vontade voltou, e há sete anos, Gabriel despertou o interesse de ter um Fusca de novo e comprou um Fusca 1970, bege, de seu primo. E Fusca para Gabriel remete os anos 70, e segundo ele especificamente os "pegas" que aconteciam no alto da Boa Vista, participava constantemente, pois diz ser uma pessoa que adora adrenalina. Gabriel fala do relacionamento com seu carro com amor, sua esposa estava do lado quando eu o entrevistei e falou um pouco da relação dos dois com o Fusca, das viagens que fazem para a Região dos lagos com o Fusca, pois é o único carro do casal, e ela falava que todas eram sempre prazerosas. Gabriel cita o design e ser um carro robusto como sendo as características mais fortes do Fusca e não tem nada de negativo a dizer, o carro aguenta qualquer situação segundo Gabriel. Finaliza a entrevista com a palavra prazer, e segundo amor, pois o primeiro é a sua mulher Juliana, o motivo de dirigir e ter o Fusca em suas mãos.

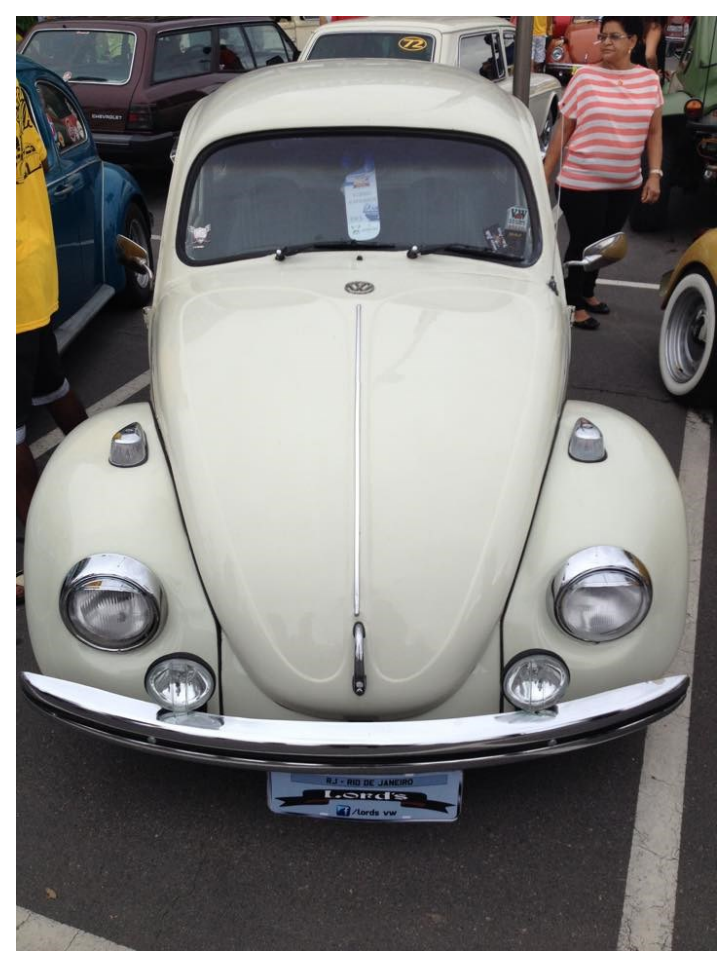

Figura 22: Fusca do Gabriel ano 70

Fonte: Autor 
"O Fusca é a minha paixão, na verdade é a minha segunda paixão por que a primeira é a minha mulher, mas o prazer de dirigir um Fusca é único."

A nona entrevista foi com o Marcelo, 54 anos, professor de Química no colégio Miguel Couto. Marcelo conta que seu primeiro contato com o Fusca foi na adolescência, foi o seu primeiro carro, aprendeu a dirigir nele, era um carro barato e ganhou do pai um Fusca 68 apelidado de Ximbica. Conta que há dez anos resolveu comprar um Fusca e, através do bomnegocio.com, comprou a Suzana Vieira, um Fusca 77 de cor bege, Marcelo explica o porquê a escolha do apelido Suzana Vieira, porque é velho, mas quando as pessoas o veem, sempre querem passar a mão. Para Marcelo, o Fusca representa um estilo de vida, um padrão, o estar junto com amigos, com a família, as viagens com a esposa e lhe remete também a saudosismo. Marcelo conta que dirige o Suzana nos finais de semana e em eventos de veículos antigos principalmente e fala sobre seu relacionamento com seu carro, que se resume em paixão e amor. Para Marcelo as características mais fortes são o motor robusto que não te deixa na mão, a mecânica simples, e segundo ele uma expressão conhecida no mundo dos "fusqueiros" é que com um arame e um chiclete se conserta um Fusca. Quanto a pontos negativos ele não cita nenhum, mas comenta a tecnologia que, para época que estamos não tem por que colocar pontos negativos. Uma situação marcante que Marcelo contou foi com seu primeiro Fusca ,o 68, que fez uma viagem para o noroeste do estado do Rio de Janeiro e que a viagem demorou um torno de 14 horas, onde normalmente demoraria 5 horas devido a paradas constantes do Fusca. Marcelo não possui um mecânico fixo, mas sempre procura os mais velhos e de preferência os mais rabugentos, pois segundo ele são os que mais entendem já os mecânicos mais jovens não querem saber de Fusca, porque as peças são baratas e não dá dinheiro. Finalizando, ele resume em "Liberdade" o fato de ser um proprietário do Suzana Vieira.

"Fusca é um estilo de vida, é estar junto com amigos, um pouco de saudosismo, de saudades da família e de viajar com a esposa." 


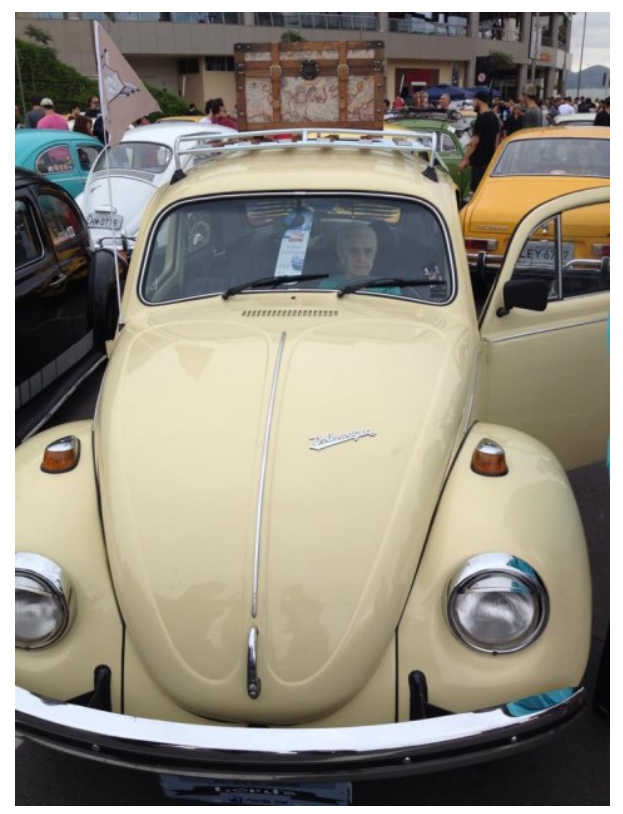

Figura 23: Suzana Vieira ano 1977.

Fonte: Autor

A décima entrevista foi com o Otavio, com participações de sua mulher Letícia, estão casados há 35 anos, Otavio tem 75 anos e é advogado. O primeiro contato de Otavio com o Fusca foi a primeira aquisição da família, um Fusca vermelho 1969, zero quilômetro, e desde então o Fusca está na posse da família, Otavio é filho único e herdou o carro quando seu pai faleceu, o carro já está na família há quarenta e cinco anos. O Fusca para ele é tradição, e segundo ele foi uma pena ter parado de ser fabricado. Quando perguntado sobre o relacionamento dele com o carro, Otavio chorou, pois veio uma lembrança muito forte dos tempos da família, de seu pai principalmente, e resumiu em carinho. Hoje, por um problema de saúde, não tem mais condições de dirigir o Fusca, mas sua mulher o leva para passear constantemente e, quanto às características fortes, ele cita a força do carro, suportar qualquer estrada e tipos de terrenos e o design. O apelido ficou fusquinha, pois era como seu pai o chamava e assim ficou. Quanto a mecânica, Otavio é bastante especifico, faz a troca de óleo a cada $5.000 \mathrm{~km}$ e utiliza apenas o óleo Havoline e só coloca gasolina Podium dos postos BR, e segundo ele, é o motivo para o Fusca em 45 anos nunca ter dado problemas e nunca ter deixado na mão, além de uma manutenção de rotina. Encerrando a entrevista Otavio, resume em alegria sempre o prazer de ter e dirigir o fusquinha herdado de seu pai. 
"Fusca é uma tradição, um carro que se Deus quiser não acaba nunca, mas é um carro que quem gosta, gosta. Ele enfrenta qualquer tipo de estrada (..) O relacionamento com o meu Fusca é um relacionamento de carinho e paixão, por ter sido do meu pai e estar na família desde sempre é um carinho enorme."

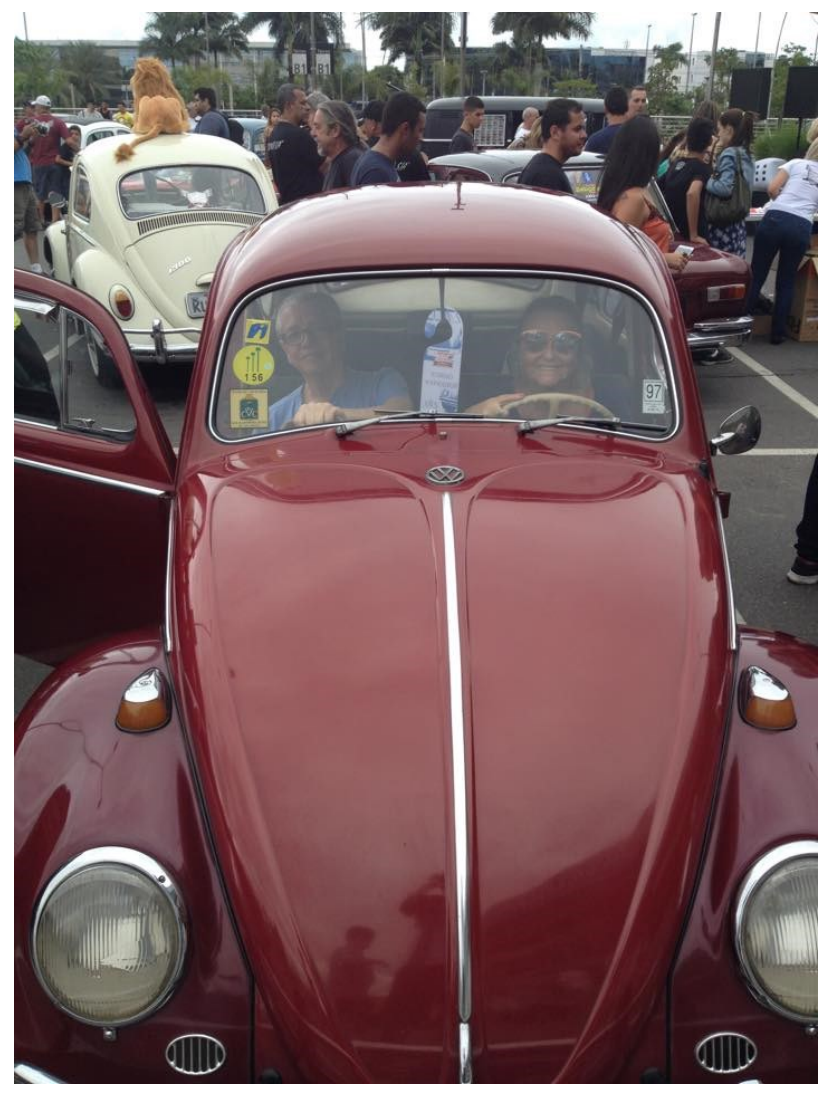

Figura 24: Otavio e sua mulher no Fusca ano 1969.

Fonte: Autor

A decima primeira entrevista e última foi com o Jorge, 44 anos, contador. $O$ primeiro contato com o Fusca de Jorge aconteceu na adolescência, foi o carro que aprendeu a dirigir e que seu pai lhe deu. Jorge sempre gostou de carros antigos, sempre participava de encontros como o Low Bugs, que ocorre no parque da Lagoa Rodrigo de Freitas, Rio de Janeiro, uma vez por mês e há aproximadamente 10 anos a paixão voltou e decidiu comprar um Fusca azul 1968 através de sites de compras. Jorge fala que Fusca para ele remete a um estilo e vida, um estilo de ser e que seu relacionamento com seu carro é de prazer, um hobby, é uma terapia, onde ele esquece os problemas da vida e se concentra apenas no carro. Além de ter outro carro por se fazer necessário, 
Jorge diz que o dirige em torno de três vezes por semana e que está presente constantemente em eventos. Quanto à relação de amigos família e colegas de trabalho, Jorge conta que alguns o chamam de maluco por investir dinheiro mais que o necessário, Jorge modificou o carro quase inteiro, colocou um teto solar, retrovisores estilizados, painel, volantes e estofado. Uma situação marcante que Jorge conta foi uma viagem com os amigos na juventude em que o carro enguiçou na estrada e até que um carro parou para ajudar, depois para mais outro e acabou formando um comboio de carros ajudando a empurrar até o mecânico mais próximo. Outra história com o Fusca atual foi quando ele foi resgatá-lo, já havia comprado e o carro estava em São Paulo, ele estava fazendo uma viagem a trabalho, chegou ao Rio e pegou um taxi direto para São Paulo buscar o carro, segundo ele queria pegar o carro o quanto antes. Quanto a pontos fortes, Jorge cita a durabilidade do veículo e finalizando ele resume em nostalgia, voltar ao passado e reviver um tempo glamoroso que o Brasil vivia na época do Fusca.

"Na minha família já teve cinco Fuscas, e para mim Fusca é um estilo de ser, é uma terapia aonde eu saio da rotina, seja mexendo na mecânica seja dando uma volta com ele pela orla da praia."

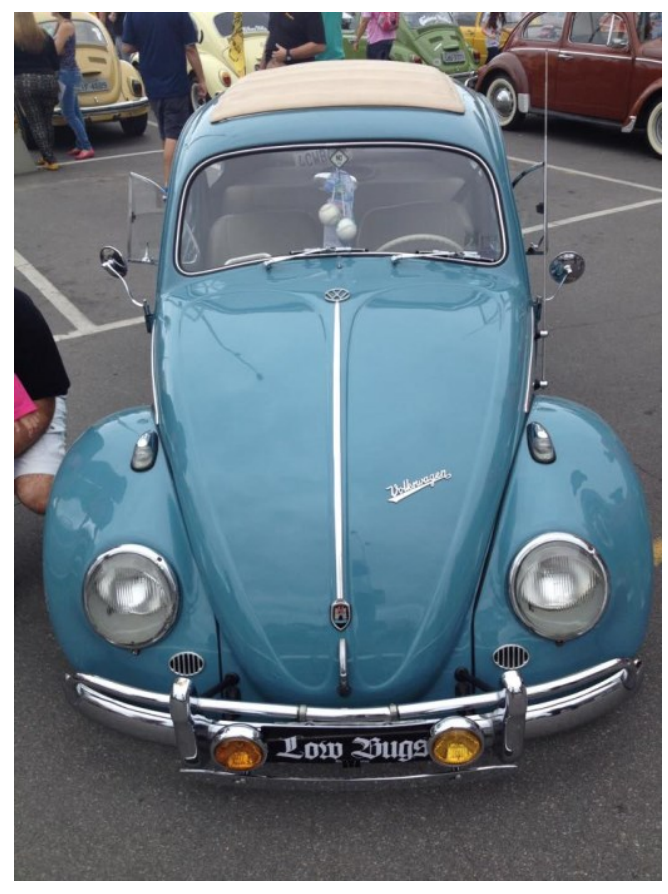

Figura 25: Fusca 1968 do Jorge.

Fonte: Autor 
Portanto, após realizar e analisar todas as entrevistas, pode se perceber que todos demonstram um enorme carinho, paixão pelo Fusca. A idade dos entrevistados foi bem abrangente, porém pode-se perceber respostas semelhantes, quanto às características mais fortes do veículo como o design, o motor robusto, a simplicidade do carro, a capacidade de andar em diversos terrenos foi citada em mais de três entrevistas, além da relação entre o dono e o carro, onde ficou mais explícito na entrevista do Otavio, 75 anos, que quando perguntado, seu olho encheu de lágrimas falando do carinho e da representação do Fusca em sua vida. O sentimento de liberdade também foi bem falado, e o sentimento de nostalgia foi citado por entrevistados mais velhos e por alguns mais novos pelo fato de ter herdado ou tido um contato na infância e que foi marcante. 


\section{Conclusões}

Esse trabalho pretendeu entender quais motivos, valores levaram os proprietários de Fusca a comprarem e/ou manterem o carro até os dias de hoje. Também pretendeu entender o relacionamento e a compreensão que existe entre o Fusca e seus donos. Após o estudo foi possível começar a entender as emoções envolvidas, são elas emoções de carinho, nostalgia, prazer, liberdade paixão. Através das entrevistas pôde-se perceber que quanto mais velho o proprietário é, mais carinho se tem, porém os mais novos também se referiam ao seu Fusca paixão e prazer.

Para aprofundar a ánalise, investigou-se a perspectiva de Solomon (2008), Churchil e Peter (2000) McCraken (2003) Kotler e Keller (2006), Schiffman e Kanuk (2009) e Abdala, Fleck e Trott (2008) acerca dos temas como comportamento do consumidor e cultura, estilos de vida e como a nostalgia afeta o comportamento do consumidor.

A metodologia utilizada de entrevista em profundidade se fez necessária para poder alcançar o objetivo do estudo, o método de entrevistas possibilitou revelar sentimentos e valores cruciais para o entendimento de suas relações com o Fusca. Todos os entrevistados residem na cidade do Rio de Janeiro, porém acredita-se que as relações não mudariam e que palavras semelhantes seriam citadas caso os entrevistados residissem em outros estados, pois o Fusca foi muito presente em todo o país e ainda é possível ver clube de Fuscas em diversos estados do Brasil.

Os resultados alcançados indicam que a questão da nostalgia, a representação simbólica, os bons momentos vividos, o prazer, o carinho e o sentimento de liberdade, foram os motivos que os proprietários compraram e mantiveram seus Fuscas até os dias de hoje. 


\section{Referências Bibliográficas}

CARVALHO, E.G; Inovação tecnológica na indústria automobilística: Características e evolução recente. São Paulo.2007 Faculdade de Ciências e Letras da Universidade Estadual Paulista Júlio de Mesquita Filho (Unesp)

CAMPOS, C.J.C Métodos de Análise de Conteúdo: ferramenta para a análise de dados qualitativos no campo da saúde. Brasília.2004 Revista Brasil Enfermagem.

CHURCHILL, G. A. e PETER, J. Paul. Marketing: criando valor para os clientes. São Paulo: Saraiva, 2000.

ENCICLOPÉDIA Larousse Cultural. São Paulo. 1998

GODOY, A.S Revista de Administração de Empresas. A pesquisa qualitativa e sua utilização em administração de empresas / EAESP / FGV, São Paulo, Brasil .1995

KATAOKA, Fabio. Fusca: Uma Paixão, O carro mais amado do Mundo, São Paulo, Escala, 2008.

KOTLER, Philip; KELLER, Kevin L. Administração de marketing. 12. ed. São Paulo: Pearson Prentice Hall, 2006.

MILETO, C; PEREIRA, J; AZEVEDO, V. Comportamento de consumo do retro na internet: estudos de nostalgia, identidade e memória. Intercom XXXVIII Congresso Brasileiro de Ciências da Comunicação - Rio de Janeiro, 2015.

MCCRACKEN, G. Cultura e Consumo. Rio de Janeiro. Maud. 2003

PORTUGAL, Maria. Site. 8 marcas que estão se beneficiando da nostalgia. Exame, 2013

Disponível em: www.exame.abril.com.br.

SCHFFMAN, Leon G; KANUK, Leslie L. Comportamento do consumidor. Tradução de Dalton Conde de Alencar. 9. Ed. Rio de Janeiro: LTC, 2009

SOLOMON, M. R. Comportamento do Consumidor: Comprando, possuindo e 
sendo. 5a. Edição. Porto Alegre: Bookman, 2000.

SOUZA, L.V; POLIDORIO.G.R.S. O Poder da nostalgia no processo de conquistas de clientes. ETIC - Encontro de Iniciação Cientifica.2013 


\section{Anexo 1}

Roteiro realizado com proprietários de fuscas.

1. Nome / Idade / Bairro / Profissão

2. Como foi seu primeiro contato com o fusca?

3. Conte como foi que passou a ser proprietário de um Fusca?

4. Já teve mais de um fusca?

5. Quando falo em "fusca" o que vem à sua cabeça?

6. Fale um pouco sobre a sua relação com o seu carro. Como descreveria seu relacionamento com o seu Fusca?

7. Por que você acha que se sente/ se relaciona dessa forma com o seu Fusca?

8. Você tem outro carro além do Fusca? Por quê?

9. Com que frequência você dirige seu Fusca? Em que ocasiões dirige seu fusca?

10. O que o Fusca representa na sua vida?

11. Como outras pessoas (família, amigos, colegas de trabalho) percebem o relacionamento que você tem com o seu fusca?

12. Para você, quais são as características mais fortes do Fusca?

13. Para você, o carro tem algum ponto negativo?

14. Você deu algum apelido para seu Fusca?

15. Conte alguma situação marcante que passou com o fusca.

16. Já passou por algum embaraço problema ou dificuldade devido ao fusca? Se sim, fale um pouco sobre isso.

17. Como é a manutenção do fusca? Você acha que ter um fusca demanda cuidados especiais? Quais, como são feitos e com que frequência?

18. Descreva-me em uma palavra, qual a sensação de dirigir/ ter um fusca? 